\title{
IMPACT OF MINIMUM WINTER TEMPERATURES ON THE POPULATION DYNAMICS OF DENDROCTONUS FRONTALIS
}

\author{
J. Khải Trần, ${ }^{1,5}$ Tinna Ylioja, ${ }^{2}$ Ronald F. Billings, ${ }^{3}$ Jacques Régnière, ${ }^{4}$ and Matthew P. Ayres ${ }^{1,6}$ \\ ${ }^{1}$ Department of Biological Sciences, Dartmouth College, Hanover, New Hampshire 03755 USA \\ ${ }^{2}$ Finnish Forest Research Institute, Suonenjoki Research Station, Juntintie 154, FI-77600 Suonenjoki, Finland \\ ${ }^{3}$ Texas Forest Service, 301 Tarrow, College Station, Texas 77840 USA \\ ${ }^{4}$ Natural Resources Canada, Canadian Forest Service, Sainte-Foy, QC, Canada G1V 4C7
}

\begin{abstract}
Predicting population dynamics is a fundamental problem in applied ecology. Temperature is a potential driver of short-term population dynamics, and temperature data are widely available, but we generally lack validated models to predict dynamics based upon temperatures. A generalized approach involves estimating the temperatures experienced by a population, characterizing the demographic consequences of physiological responses to temperature, and testing for predicted effects on abundance. We employed this approach to test whether minimum winter temperatures are a meaningful driver of pestilence from Dendroctonus frontalis (the southern pine beetle) across the southeastern United States. A distance-weighted interpolation model provided good, spatially explicit, predictions of minimum winter air temperatures (a putative driver of beetle survival). A Newtonian heat transfer model with empirical cooling constants indicated that beetles within host trees are buffered from the lowest air temperatures by $\sim 1-4^{\circ} \mathrm{C}$ (depending on tree diameter and duration of cold bout). The life stage structure of beetles in the most northerly outbreak in recent times (New Jersey) were dominated by prepupae, which were more cold tolerant (by $>3^{\circ} \mathrm{C}$ ) than other life stages. Analyses of beetle abundance data from 1987 to 2005 showed that minimum winter air temperature only explained $1.5 \%$ of the variance in interannual growth rates of beetle populations, indicating that it is but a weak driver of population dynamics in the southeastern United States as a whole. However, average population growth rate matched theoretical predictions of a process-based model of winter mortality from low temperatures; apparently our knowledge of population effects from winter temperatures is satisfactory, and may help to predict dynamics of northern populations, even while adding little to population predictions in southern forests. Recent episodes of $D$. frontalis outbreaks in northern forests may have been allowed by a warming trend from 1960 to 2004 of $3.3^{\circ} \mathrm{C}$ in minimum winter air temperatures in the southeastern United States. Studies that combine climatic analyses, physiological experiments, and spatially replicated time series of population abundance can improve population predictions, contribute to a synthesis of population and physiological ecology, and aid in assessing the ecological consequences of climatic trends.
\end{abstract}

Key words: adaptive seasonality; bark beetle; climate change; cold tolerance; Dendroctonus frontalis; distribution limits; lower lethal temperature; microclimate; pest management; population dynamics and monitoring; Scolytinae; southern pine beetle.

\section{INTRODUCTION}

A fundamental problem in applied population biology is the development of validated models to predict population dynamics. Accurate predictions are important for setting harvest targets of fish and game populations (Georgiadis et al. 2003), directing control of pest populations (Shirley et al. 2001), predicting disease occurrence (Pascual et al. 2000), and managing the risks for threatened and endangered species (Kokko

Manuscript received 28 March 2006; revised 1 August 2006; accepted 14 August 2006. Corresponding Editor: H. P. Schmid.

${ }^{5}$ Present address: Department of Ecology and Evolution, State University of New York at Stony Brook, Stony Brook, New York 11794-5245 USA.

${ }^{6}$ Corresponding author.

E-mail: Matthew.P.Ayres@dartmouth.edu et al. 1997). Because many species have widespread distributions with spatially heterogeneous dynamics (Lele et al. 1998, Bjørnstad et al. 1999, Sharov et al. 1999, Gurney et al. 2001), there is often a need for models that can generate spatially explicit population predictions.

Population models can be based upon endogenous feedbacks (depending on abundance or density) and/or exogenous drivers (operating independently of abundance or density) (Turchin et al. 1991, Turchin and Taylor 1992, Aanes et al. 2000, Jenouvrier et al. 2003, Ahumada et al. 2004). There is an almost infinite number of theoretically possible exogenous drivers, but temperature is a common general candidate. Environmental temperature has universally strong effects on animal physiology (Huey and Hertz 1984, Nedved et al. 1998, Brown et al. 2004) and widespread effects on 
populations (Sæther et al. 2000, Aars and Ims 2002, Altwegg et al. 2005, Carrillo et al. 2005a). In many parts of the world, air temperatures are carefully monitored and efficiently reported. This creates an opportunity for developing spatially extensive models to predict the trajectory of population abundance based upon local temperatures, but examples in the literature are rare.

A generalized approach for modeling climatic effects on population dynamics involves three components.

1) Accurate prediction of the physiological effects of temperature on the study organisms. The literature contains thousands of empirical studies that provide such data (Stevenson and Bryant 2000, Bale 2002, Humphries et al. 2004, Lourdais et al. 2004, Freon et al. 2005, Helmuth et al. 2005). This is a rich resource for managers, although application of these data can be complicated by the potential for local adaptation and acclimatization (Kukal et al. 1991, Ayres and Scriber 1994, Dittman 1997, Layne et al. 1999, Broggi et al. 2004).

2) Accurate prediction of temperatures experienced by the study organism in its immediate environment. Commonly, this may involve micro-meteorological models to go from routinely collected records at established weather stations to microsite temperatures within the appropriate habitats (Bolstad et al. 1997, Régnière and Sharov 1999, Kearney and Porter 2004).

3) Testing for predicted population effects. Demographic predictions from 1 and 2 should be confronted with empirical time series of abundance. All population models are simplifications. A good model is one that includes drivers that are important enough to influence population dynamics. Evidence of physiological effects on individuals is not sufficient to infer demographic importance because other forces might be more important than the hypothesized driver.

Consideration of components 1 to 3 above can permit the validation, refutation, or refinement of theoretical models that relate climatic variables to population dynamics. If a population model based on physiology and microclimate successfully predicts the dynamics of independent abundance data, then the overall theoretical model is validated. If the model fails to provide satisfactory predictions, there may be a weakness in either the physiological or climatic components, which may then be refined, or the hypothesized driver of population dynamics is simply not strong enough to have applied value and consideration should shift to other drivers. We employed this three-level approach to evaluate the effects of winter temperatures on population dynamics of the southern pine beetle, Dendroctonus frontalis Zimmermann (Coleoptera: Scolytinae) across its distribution in the southeastern United States. This study built on previous ones that have implicated minimum winter temperature as a factor in the survival and northern distribution limits of $D$. frontalis (Ungerer et al. 1999, Lombardero et al. 2000).
Study system

The southern pine beetle reproduces by killing mature pine trees, and its populations frequently attain epidemic proportions (Turchin et al. 1991, Ylioja et al. 2005). It is by far the most important source of biotic disturbance in pine forests of the southeastern United States (Price et al. 1997), and is among the most economically and ecologically important sources of forest disturbance in North America (Ayres and Lombardero 2000, Dale et al. 2001). Based upon a composite historical record, the range of the southern pine beetle covers the southeastern United States, from southern New Jersey and Pennsylvania to southern Missouri, south to east Texas, and east into Florida. The insect is also found in Arizona through Mexico and as far south as Nicaragua (Thatcher et al. 1980, Billings et al. 2004). Outbreaks at the northern limits of the southern pine beetle's range, where it has historically been rare, have occurred in recent years. New Jersey suffered from outbreaks beginning in 2001 and continuing to the present (2006), where no outbreaks had been recorded since 1939 (Wilent 2005). Maryland experienced outbreaks in Talbot County for the first time in 2005, and Ohio reported outbreaks in 2001 (Wilent 2005). Ungerer et al. (1999) predicted a northern expansion of southern pine beetle outbreaks should there be an increase of minimum winter air temperature.

In this study, we tested the hypothesis that minimum winter temperature is a meaningful driver of broad spatiotemporal patterns in the epidemiology of southern pine beetle populations. A priori, there was a strong case for the importance of winter temperatures in southern pine beetle population dynamics. Notable winter mortality of natural populations has occurred when air temperatures dropped below approximately $-12^{\circ} \mathrm{C}$ (e.g., Beal 1933, McClelland and Hain 1979, others cited in Ungerer et al. 1999). Lombardero et al. (2000) measured the supercooling points (temperature of crystallization) of adults, pupae, and feeding larvae of the southern pine beetle. They found that the lower lethal temperature for adults, which corresponded to the supercooling point, averaged $-12.1^{\circ} \pm 4.0^{\circ} \mathrm{C}$ (mean $\left.\pm \mathrm{SD}\right)$, did not change seasonally, and was not affected by various acclimation regimes. These authors showed that momentary exposure to temperatures at or below the supercooling point was lethal to southern pine beetles, while even prolonged exposure to slightly warmer temperatures produced little mortality. Ungerer et al. (1999) also showed a concordance between the historical northern distribution limits of the southern pine beetle and the annual occurrence of at least one winter night when air temperature dropped below $-16^{\circ} \mathrm{C}$ (which they judged should result in $>90 \%$ mortality of the beetle population, allowing for the inner pine bark being $1^{\circ} \mathrm{C}$ warmer due to thermal buffering). Based on existing physiological studies, Ungerer et al. (1999) predicted that the relative growth rate of beetle populations from one summer to the next would drop sharply when the minimum winter air temperature 
dropped below approximately $-16^{\circ} \mathrm{C}$. Among the limitations of this work were that: (1) physiological studies were restricted to one population from northern Alabama; (2) climatic models were based on only 50 weather stations and ignored potential differences in temperature between the stations and trees, due to differences in elevation or microclimate (e.g., exposure); and (3) there were no direct tests of demographic effects in natural populations.

Here we developed a spatial interpolation method to predict minimum winter air temperature in study forests using observations from a large number of weather stations, and tested for a historical trend of warming minimum winter air temperatures that might account for the recent spate of northern outbreaks of $D$. frontalis. We studied cold tolerance in the most northerly population of $D$. frontalis and evaluated the relationship between air temperature and phloem temperatures experienced by bark beetles. Finally, we tested the population predictions from climatic modeling and physiological measurements against more than a decade of surveys of southern pine beetle abundance in forests throughout the southeastern United States.

\section{Methods}

\section{Predicting minimum air temperatures in study forests}

Since 1987, a growing network of forest health professionals have been participating in a standardized protocol of pheromone-based trapping to estimate the abundance of southern pine beetle during the spring dispersal phase (Billings 1988). By 2004, this network included 140 forests. Sampling locations include U.S. National Forest Ranger Districts, state forests, military lands, and privately owned loblolly pine (Pinus taeda) forests. Data are compiled annually by the Texas Forest Service (available online). ${ }^{7}$

The exact locations of the traps are not known and may vary from year to year. Therefore, we referenced the data spatially by assigning coordinates to the middle of each forest area, which should generally have been within $10 \mathrm{~km}$ of actual trapping locations. This sampling program had high value for our research questions because it is unusually extensive in space and time. A limitation is that these are operational data that have been collected by many different people for management purposes, and not for research. If we had designed the sampling for our research question, we probably would have included more trapping locations per forest to reduce the sampling variance in population estimates for each forest in each year.

The putative climatic driver in this study is the minimum winter air temperature (the lowest minimum temperature from July of the preceding year to June of each year). Minimum daily temperatures for 1987-2004 were obtained for all weather stations across the southeastern United States, from Texas and Florida in the south to Tennessee and Maryland in the north, from the NOAA online data acquisition system (available online). ${ }^{8}$ The median distance from forests with beetle abundance data (Fig. 1) to the nearest weather station was $16 \mathrm{~km} ; 97.5 \%$ were within $40 \mathrm{~km}$, with a maximum distance of $71 \mathrm{~km}$. We extracted the minimum winter air temperature for each station in each year for which records were complete (data from 1157 stations with 517 winters for each station).

We used a spatial interpolation method to estimate minimum winter air temperature in each year for each forest with beetle abundance data. After preliminary testing of various spatial interpolation techniques, including spatial regression and kriging, we developed our own distance-weighted procedure, because it produced slightly more accurate estimates:

$$
T_{u}=\frac{\sum\left(T_{i} \times D_{i}^{-\lambda}\right)}{\sum D_{i}^{-\lambda}}+\left[\frac{\sum\left(E_{i} \times D_{i}^{-\lambda}\right)}{\sum D_{i}^{-\lambda}}-E_{u}\right] \times \ell
$$

where $T_{u}=$ minimum winter air temperature at site $u, T_{i}$ $=$ minimum winter air temperature recorded at weather station $i, D_{i}=$ distance from site $u$ to weather station $i, E_{i}$ $=$ elevation of weather station $i, E_{u}=$ elevation at site $u, \lambda$ $=$ distance weighting coefficient, and $\ell=$ an elevation weighting coefficient. The distances between weather stations and beetle sites (in meters) were calculated assuming the earth is a sphere. The distance coefficient $\lambda$ and elevation coefficient $\ell$ were estimated using the Generalized Reduced Gradient (GRG2) algorithm (Microsoft Excel solver) to minimize the average crossvalidation root mean square error across years. In crossvalidation, observations are withheld and estimated one by one; then squared differences between observed and estimated values are summed and averaged to provide the mean square error.

\section{Time trend in air temperatures}

Of the NOAA weather stations retained above, we identified 76 stations representing 12 states (AL, AR, FL, GA, LA, MD, MS, NC, SC, TN, TX, and VA) that had nearly complete data from 1960 through 2004, with no more than five years with any missing daily minimum temperatures. We chose 1960 as a starting point because this marks the earliest systematic records of $D$. frontalis damage across the region (Price et al. 1997). For each of these stations, we calculated the average minimum winter air temperature over the 44-year series and calculated residuals for each year from this long-term average. The mean residual of minimum winter air temperature for each year (averaged across stations) was regressed against year.

Because these analyses showed a surprisingly strong warming trend, we went on to test for patterns with respect to latitude, longitude, elevation, and local

${ }^{8}\langle$ http://www.ncdc.noaa.gov/oa/ncdc.html $\rangle$ 


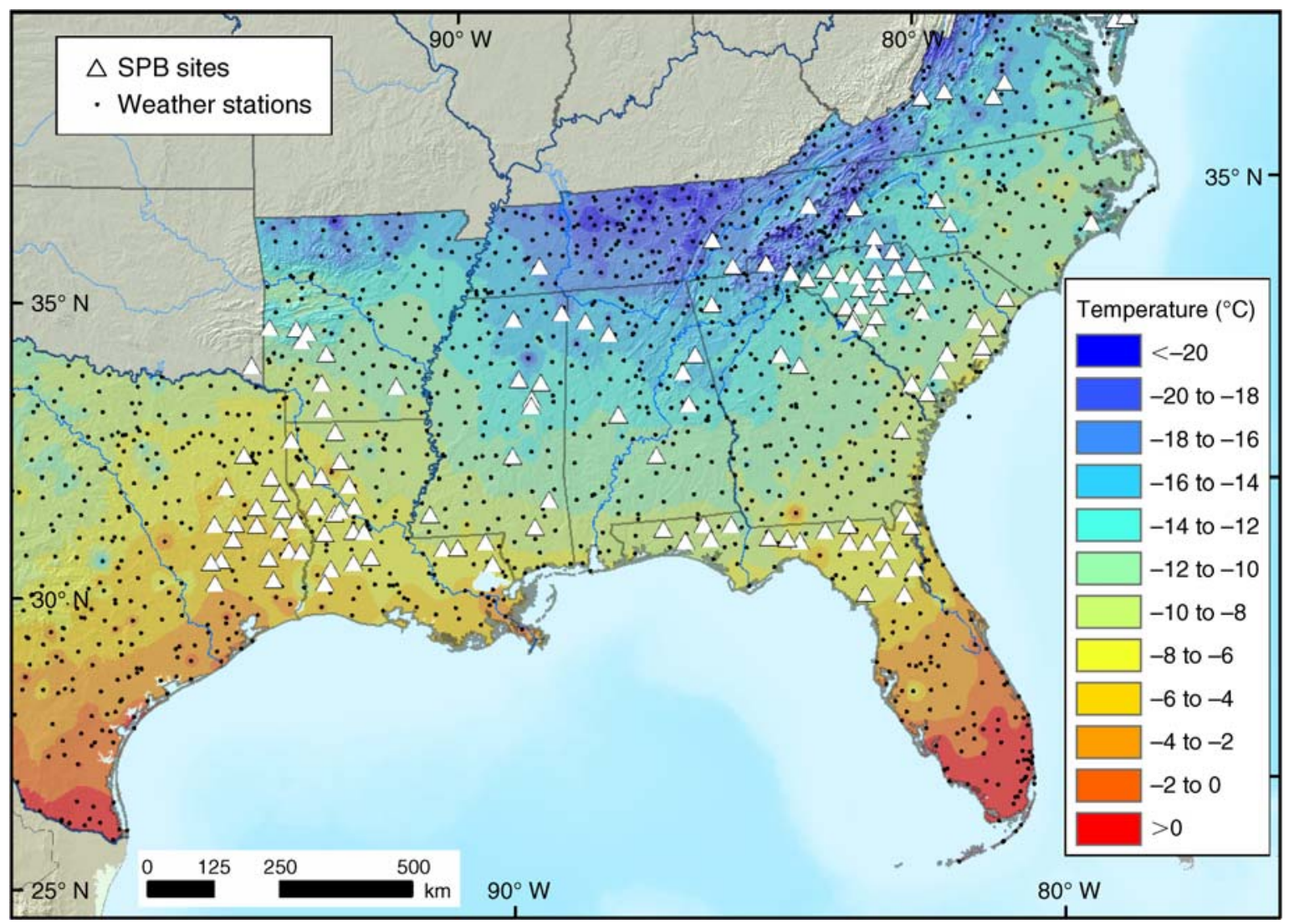

FIG. 1. Minimum air temperatures (in ${ }^{\circ} \mathrm{C}$ ) in the southeastern United States during the winter of 2003-2004, calculated using Eq. 1. The locations of southern pine beetle (SPB) sites and weather stations are shown. We constructed separate models for each year from 1987 to 2004 to estimate minimum winter air temperatures at each southern pine beetle site.

human population density. The population density check tested if the pattern might be a consequence of urban heat islands (Jin et al. 2005), and therefore not necessarily relevant to the forests inhabited by $D$. frontalis. We extracted human population densities (2000 census, $100 \%$ data, for 5-digit zip code tabulation areas containing each climate station (mean area $\pm \mathrm{SD}=$ $479 \pm 372 \mathrm{~km}^{2}$ ) (U.S. government census data, available online). ${ }^{9}$ For each of the 76 climate stations, we calculated the slope of minimum winter air temperature vs. year, and then evaluated all possible linear regressions to predict these individual slopes as a function of latitude, longitude, elevation, their two-way interactions, (latitude) $)^{2}$, (longitude) ${ }^{2}$, and $/$ or $\log$ (people $/ \mathrm{km}^{2}$ ) (transformation to improve normality).

\section{Phloem temperatures}

Beal (1934) showed that thermal buffering in Pinus ponderosa varied with bark thickness and could be as great as $12^{\circ} \mathrm{C}$. However, Ungerer et al. (1999) and Bolstad et al. (1997) have discounted the potential variability in thermal buffering and used estimates of 1-

${ }^{9}\langle$ http://www.census.gov/ $\rangle$ $2^{\circ} \mathrm{C}$ of buffering in daily thermal minima within the phloem compared to air. To better understand the variability in thermal buffering, we tested a model based on Newton's Law of Cooling, in which the rate of change in temperature of an object is proportional to the difference between the ambient temperature and that of the object (in this case, phloem):

$$
T_{t+\Delta t}=T_{t}+K\left(A_{t+\Delta t}-T_{t}\right) \Delta t
$$

where $T_{t+\Delta t}$ and $A_{t+\Delta t}=$ phloem and air temperature at time $t+\Delta t$, respectively, $T_{t}=$ phloem temperature at time $t$, and $K=$ the cooling constant (units of $t^{-1}$ ), and $\Delta t$ is a small time step (e.g., one hour).

Paired thermocouples (Type T) connected to dataloggers (LogBox, Ocean Controls, Balnarring, Australia) were used to monitor air and phloem temperatures at intervals of $\Delta t=0.25-1$ hour in nine pine trees at five localities: DeSoto Ranger District, Mississippi (JulyAugust 2004); Oakmulgee Ranger District, Alabama (May-June 2005); York, Pennsylvania (20-25 December 2004), and two sites in Cape May Court House, New Jersey (February-April 2005). Trees ranged in size from 15 to $50 \mathrm{~cm}$ diameter at breast height. On each tree, at $1.5 \mathrm{~m}$ height, one sensor was placed in the air $8-10 \mathrm{~cm}$ 
from the tree, and the other was inserted through the outer bark via a minimal tangential incision $(1 \mathrm{~mm}$ diameter) into the thin (1-3 mm) phloem layer where $D$. frontalis would occur; the incision was then sealed with a spot of silicone. Like most pine forests inhabited by $D$. frontalis, these forest canopies were largely closed, and there was little solar warming of tree trunks (usually $<1^{\circ} \mathrm{C}$ difference in phloem temperatures among trees within a stand or between sides of trees that are shaded vs. sunlit). Estimates of $K$ for each tree were obtained by fitting Eq. 2, using the Generalized Reduced Gradient (GRG2) algorithm to minimize the RMSE of predicted phloem temperatures at each time step, to data from each locality using observed phloem temperature at $t=0$ as an initial condition. Predicted phloem temperatures at subsequent time steps were based on current observed air temperature and the previous time step's predicted phloem temperature.

This model implies that the degree of thermal buffering is highest when $K$ is low (likely related to the size of tree and thickness of bark), temperatures prior to the cold temperature are relatively warm, and the duration of the cold temperature is short. To estimate thermal buffering in pine forests with $D$. frontalis, we applied Eq. 2 to 140 historical time-series of hourly temperatures during midwinter (1 December to 28 February) that were available for seven recent years (1998-2005) from 25 NOAA climate stations distributed across 16 states (AL, AR, CT, DE, GA, IL, KY, MD, MS, NC, NJ, PA, SC, TN, VA, and WV) in the region of interest. For each winter record at each site, we used different values of $K$ to calculate the expected minimum phloem temperature during the three-month period (excluding the first three days) minus the observed minimum air temperature. This yielded a frequency distribution for any $K$ of expected thermal buffering under historical winter temperatures.

\section{Physiological measurements of cold tolerance}

To test for regional differences in the lower lethal temperature for the southern pine beetle, we measured the supercooling points for adults from the Oakmulgee Ranger District of the Talladega National Forest, Alabama, and Cape May Court House, New Jersey, collected in November 2004, as well as other life stages from New Jersey, collected in February 2005. Thermocouples were attached with tape to the surface of individual beetles, which were then slowly cooled in an air chamber within a low-temperature water bath. As cooling proceeded, the temperature of each individual beetle was recorded at one-second intervals using a 16channel recorder (THERMES data acquisition system, Physitemp Instruments, Incorporated, Clifton, New Jersey, USA). The instant when each beetle froze was marked by a conspicuous exotherm from the heat of fusion. Supercooling points were taken as the temperature of the insect immediately preceding the exotherm. Most measurements employed a standard linear cooling rate of $-0.2^{\circ} \mathrm{C} / \mathrm{min}$ (e.g., Lombardero et al. 2000) but we also conducted two trials with a very slow cooling rate of $-0.04^{\circ} \mathrm{C} / \mathrm{min}$ to verify that this experimental detail did not affect supercooling points. Following freezing, individuals were observed over several days at room temperature for signs of life. With the beetles collected from New Jersey in February 2005, we also measured the supercooling points of late fourth instars that had moved from the phloem into the outer bark in preparation for pupation (prepupae). Beal (1933) hypothesized this life stage to be relatively cold-tolerant in the southern pine beetle.

Our studies used supercooling points as estimates of lower lethal temperature - the temperature below which death occurs. To validate this, samples of 83-100 individuals from New Jersey were slowly cooled over 11 hours to $-13.7^{\circ} \mathrm{C},-15.6^{\circ} \mathrm{C},-17.4^{\circ} \mathrm{C}$, or $-19.7^{\circ} \mathrm{C}$, held at that temperature for one hour, and individually scored as dead or alive following several days of observation at room temperature. These experimental temperatures were calculated from the frequency distribution of independently measured supercooling points to yield mortalities of $27 \%, 51 \%, 71 \%$, or $99 \%$, respectively. We compared the observed and expected mortality frequencies with a chi-square test. We measured the supercooling points of survivors of the $-17.4^{\circ} \mathrm{C}$ treatment $(71 \%$ expected mortality) to test whether the survivors were a nonrandomly cold-tolerant subset of the population.

To determine if southern pine beetles were capable of resuming normal development following exposure to low temperatures, infested bark collected from New Jersey on 1 February 2005 was placed overnight in a freezer at $-15.3^{\circ} \mathrm{C}$, with some samples remaining at a storage temperature of $0^{\circ} \mathrm{C}$. Exposed and nonexposed bark was subsequently placed in separate emergence cans at room temperature for monitoring. Also, 100 individuals (fourth instars) removed from the bark were kept in vials to develop at room temperature without being exposed to subzero temperatures.

\section{Population growth}

The southern pine beetle trapping data were used to calculate interannual per capita growth rates $\left(R_{t}\right)$ of beetle populations as follows:

$$
R_{t}=\ln \left(N_{t}+1\right)-\ln \left(N_{t-1}+1\right)
$$

where $N_{t}$ and $N_{t-1}=$ average beetle captures per trap per two weeks in years $t$ and $t-1$. There were 1439 pairs of site-years for which we could calculate population growth rates. This sampling program also records the number of captured Thanasimus dubius (Fabricius) (Coleoptera: Cleridae). $T$. dubius is a predator of $D$. frontalis and associated bark beetles whose fluctuating abundances influence population dynamics of the southern pine beetle (Turchin et al. 1999). Thus, we tested for a relationship between minimum winter air temperature and growth rates of $T$. dubius populations. 
Southern pine beetle abundance has been measured as the number of local infestations (groups of dead and dying pines known as "spots" because of their appearance to an aerial observer) detected from aerial surveys in each year in each National Forest Ranger District or county (Billings and Ward 1984). Using these data, which have been compiled by the U.S. Forest Service Region 8 Forest Health and the Texas Forest Service, we calculated another measure of interannual population growth rates (using Eq. 3 but substituting spots per forest for beetles per trap). There were 1509 pairs of siteyears (largely the same as for the trapping data) for which we could calculate population growth rates based on the number of beetle infestations.

We used a linear threshold function to analyze the relationship between minimum winter air temperature and interannual growth rates:

$$
R= \begin{cases}a(T-c)+b & \text { if } T<c \\ b & \text { if } T \geq c\end{cases}
$$

where $R=$ interannual growth rate (trap capture of beetles or predators, number of spots), $T=$ minimum winter air temperature, $a=$ slope, $b=$ intercept, and $c=$ threshold temperature. Parameters were fit using the Generalized Reduced Gradient (GRG2) algorithm to minimize the RMSE of predicted interannual growth rates for each site-year. Eq. 4 was derived from the hypothesis that minimum winter temperatures influence population growth rate via mortality from lethal temperatures. Average minimum winter air temperature covaries geographically with the potential number of beetle generations per year $(r=0.78$ [Ungerer et al. 1999]), which might also influence population growth rate. However, we would not expect a threshold in this case because generations are numerous (4-6 per year), overlapping, and uninterrupted by diapause. We used the Akaike Information Criterion to compare the threeparameter threshold model (Eq. 4) to an alternative twoparameter linear regression derived from the hypothesis that the relationship between extreme winter temperate and $R$ is an artifact of collinearity with summer temperatures (which influence the number of generations per year).

We used quantile regression (Koenker and Bassett 1978, Cade and Noon 2003) to test if the distribution of interannual growth rates was related to minimum winter air temperature. Minimum winter air temperatures were grouped into 40 intervals containing equal numbers of observations, and growth rate deciles were determined for each interval. The linear threshold model (Eq. 4) was fitted between median minimum winter air temperature of the interval vs. interannual growth rate for each decile.

\section{A theoretical model relating climatic data} to $\mathrm{D}$. frontalis population dynamics

The demographic effect of winter temperature extremes on $D$. frontalis populations within a forest is modeled here as a function of (1) the average minimum air temperature during the winter of interest within the forest (or county) of interest, (2) spatial variation across the forest in minimum winter air temperature, (3) the relationship between minimum winter air temperature and minimum winter temperature experienced by $D$. frontalis within the phloem of its host trees, (4) the mean and variance in lower lethal temperature for $D$. frontalis of each life stage, and (5) the proportion of the population within each life stage at the time when minimum winter temperatures are experienced. This relationship is expressed by

$$
S(T)=\sum_{i=1}^{s} \sum_{j=1}^{z}\left[P_{i} \times Q_{j} \times\left(1-M_{i, j}\right)\right]
$$

where $S(T)=$ the proportion of the $D$. frontalis population expected to survive exposure to regional average air temperature $T, s=$ the number of life stages, $z=$ the number of different possible classes of experienced temperatures $h$ (here, 81 temperatures at intervals of $0.5^{\circ} \mathrm{C}$ from 0 to $-40^{\circ} \mathrm{C}$ ), $P_{i}=$ the proportion of population in each life stage, $Q_{j}=$ the proportion of $D$. frontalis that experience each temperature $h$ given regional average air temperature $T$, and $M_{i, j}=$ the proportion of each life stage $i$ with a lower lethal temperature equal to or greater than the experienced temperature $h$.

We used this model to evaluate the expected demographic consequences of new information regarding life stage structure and experienced temperatures. Scenario 1 represented baseline knowledge at the start of the present study and so followed Ungerer et al. (1999) in recognizing three life stages (larvae, pupae, and adults) with $P=0.379,0.174,0.447$, respectively (based on proportion of total development time at $25^{\circ} \mathrm{C}$ in each life stage), and with temperature-survivorship functions $(M)$ for each life stage calculated from empirical frequency distributions of supercooling points: = $-10.5^{\circ} \pm 2.9^{\circ} \mathrm{C},-8.8^{\circ} \pm 2.6^{\circ} \mathrm{C}$, and $-11.9^{\circ} \pm 2.9^{\circ} \mathrm{C}$ (mean $\pm \mathrm{SD}$ ), respectively (assuming a normal distribution of supercooling points). Also following Ungerer et al. (1999), the baseline scenario assumed that all beetles experienced a temperature $1{ }^{\circ} \mathrm{C}$ warmer than $T$ to account for thermal buffering within phloem $\left(Q_{j}=1\right.$ where $h=T+1$ and 0 otherwise). Scenario 2 accounted for local spatial variation in the temperatures experienced by beetles by using the RMSE from Eq. 1 as an estimate of the standard deviation in minimum winter air temperature among the forest stands occupied by a population of $D$. frontalis $\left(Q_{j}=\right.$ normal probability density function). Scenario 3 added new estimates of the mean and variance in thermal buffering within the phloem (see below). Scenario 4 added the presence of a cold-tolerant life stage (prepupae, see Results).

For scenario 4 , we calculated $Q_{j}$ based on a range of cooling constants ( $K$ in Eq. 2), and compared expected mortality patterns given hypothetical distributions of 


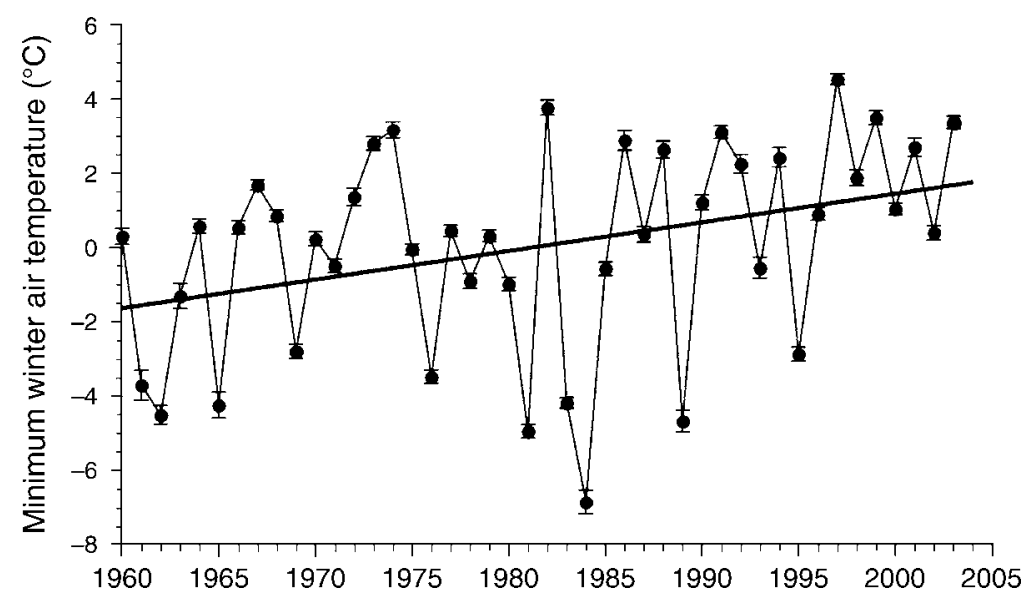

FIG. 2. Minimum winter air temperatures in the southeastern United States from 1960 to 2004. Shown are mean residuals (from mean of site) $\pm \mathrm{SE}$ (from $64-75$ sites). Slope $=0.077^{\circ} \pm 0.031^{\circ} \mathrm{C} / \mathrm{yr}(P=0.017, n=44$ years $)$.

overwintering beetles in small, medium, and large pine trees. The distribution of $D$. frontalis with respect to tree size may vary from forest to forest and year to year, but beetles tend to occur in medium-sized trees. Our approximation employed data from a recent epidemic in the Bankhead National Forest in Alabama (Ylioja et al. 2005). At the time of the epidemic, the forest contained $276 \mathrm{~km}^{2}$ of loblolly pine stands, with $50 \%$ $<33$ years of age $(10,25,75$, and $90 \%$ were $<8,23,68$, and 75 years of age, respectively). D. frontalis infestations were concentrated in stands that were 25-40 years old: stand ages corresponding to cumulative percentiles of $10,25,50,75$, and $90 \%$ were $18,28,33,38$, and 68 years. Thus we estimated that the proportion of $D$. frontalis inhabiting each of these stand age classes was $0.1,0.225,0.35,0.225$, and 0.1 , respectively. The diameter of loblolly pine at these ages tends to be $\sim 15,20,23,25$, and $51 \mathrm{~cm}$ (Baldwin and Feduccia 1987). Based on empirical estimates of $K$ vs. tree diameter (see Results), we estimated $K$ for each of these size classes as $0.221,0.175,0.156,0.141$, and $0.077 \mathrm{~h}^{-1}$. Based on these $K$ 's and historical time series of winter air temperatures (see Results), we calculated corresponding mean thermal buffering of $1.5^{\circ} \pm 0.7^{\circ}, 1.9^{\circ} \pm 0.8^{\circ}$, $2.2^{\circ} \pm 0.8^{\circ}, 2.4^{\circ} \pm 0.8^{\circ}$, and $3.9^{\circ} \pm 1.1^{\circ} \mathrm{C}$, respectively. For scenario $4, Q_{j}$ was based on mean $=T+$ average thermal buffer and variance $=$ the mean square error from Eq. $1+$ variance in thermal buffer.

\section{Results}

\section{Predicting minimum air temperatures at beetle trapping sites}

The distance-weighted spatial interpolation model (Eq. 1) provided good, spatially explicit predictions of minimum winter air temperatures across the region of interest (RMSE ranging from $1.29^{\circ}$ to $1.82^{\circ} \mathrm{C}$ ). The best overall fit was obtained with $\ell=0.00565^{\circ} \mathrm{C} / \mathrm{m}$ (lapse rate) and $\lambda=2.91$ (weighting coefficient). Estimating different values of $\ell$ and $\lambda$ for each year gave negligible improvements to the RMSE.

\section{Time trend in air temperatures}

Analysis of data from 76 climate stations in the southeastern United States showed a statistically significant increase in minimum winter air temperatures of $3.3^{\circ} \mathrm{C}$ from 1960 to 2004 (Fig. 2). When calculated separately for each station, the slope of minimum winter air temperature as a function of year was always positive $\left(\right.$ mean $\pm \mathrm{SD}=0.077^{\circ} \pm 0.033^{\circ} \mathrm{C} / \mathrm{yr}$; range $=0.002$ $0.171^{\circ} \mathrm{C} / \mathrm{yr}$ ) and tended to increase across our study area with latitude $\left({ }^{\circ} \mathrm{N}\right)$ and longitude $\left({ }^{\circ} \mathrm{W}\right)$; see Eq. $6(P<$ 0.0001 for each individual parameter; $r^{2}=0.46$, delta AIC compared to second-best model with three or fewer parameters $=14)$ :

$$
\begin{aligned}
{ }^{\circ} \mathrm{C} / \mathrm{yr}= & -3.8+0.0103 \text { (latitude) }+0.0783 \text { (longitude) } \\
& -0.00043 \text { (longitude) }{ }^{2} .
\end{aligned}
$$

Based on this regression, average minimum winter air temperature has increased from 1960 to 2004 by $2.8^{\circ}$ vs. $5.1^{\circ} \mathrm{C}$ in the south vs. the north $\left(30.75^{\circ}\right.$ vs. $\left.35.75^{\circ} \mathrm{N}\right)$, and by $2.2^{\circ}$ vs. $4.2^{\circ}$ vs. $4.1^{\circ} \mathrm{C}$ from east to west $\left(80^{\circ}\right.$ vs. $88^{\circ}$ vs. $94^{\circ} \mathrm{W}$ ). Most of our climate stations were in rural areas with relatively low human population densities (median $=43$ people $/ \mathrm{km}^{2}$ ), but there was still a 200 -fold range in human density (5 to 1005 people $/ \mathrm{km}^{2}$ ). The warming trend in Fig. 2 was not an artifact of urban heat islands, because the rate of increase in minimum winter air temperature was not related to human density $(P>0.19$ in all possible simple and multiple linear regressions). The warming trend tended to be greater with increasing elevation in the Appalachian Mountains $\left(r^{2}=0.12\right.$ for simple linear regression with elevation, $P=0.002$ ), but this pattern was absorbed by longitude in Eq. 6, and elevation contributed nothing further $(P=0.72)$.

Matched analyses of the same climate stations indicated that average annual temperature (January to 


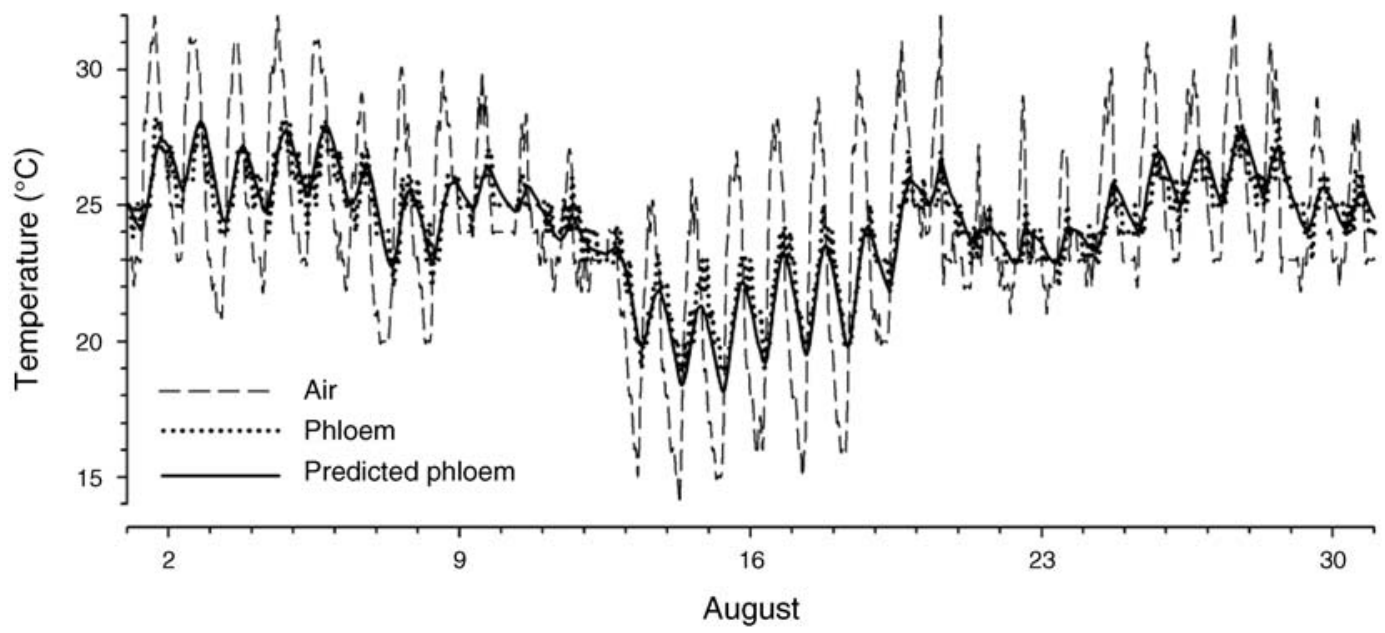

FIG. 3. Air, phloem, and predicted phloem temperatures for a tree (38 cm dbh Pinus taeda) in Chickasawhay Ranger District, DeSoto National Forest, Mississippi, for August 2004.

December) has also increased from 1960 to 2004, but by only $0.6^{\circ} \mathrm{C}$ (mean $\pm \mathrm{SE}=0.015^{\circ} \pm 0.006^{\circ} \mathrm{C} / \mathrm{yr}, P=$ 0.017 ), and that there has been no significant trend in maximum annual temperature $=0.021^{\circ} \pm 0.014^{\circ} \mathrm{C} / \mathrm{yr}, P$ $=0.15)$.

\section{Phloem temperatures}

Actual phloem temperatures closely matched those predicted by a Newtonian heat transfer model, Eq. 2 (Fig. 3). The accuracy of predicted daily minima in phloem temperatures was generally $\pm 1^{\circ} \mathrm{C}$ (RMSE in Table 1). For every tree, Eq. 2 yielded more accurate measurements of minimum daily phloem temperatures than using the average buffering for that tree (difference in RMSEs $=0.1^{\circ}-3 \cdot 2^{\circ} \mathrm{C}$ ). Two dataloggers recorded days in which the daily minimum phloem temperature was actually lower than the daily minimum air temperature by $>2^{\circ} \mathrm{C}$. This occurred on days that were much warmer than the previous day, a characteristic consistent with Eq. 2. The smallest $K$ values and highest differences in temperatures were observed in trees with the largest diameters at breast height. $K$ was related to tree diameter at breast height (in centimeters) as $(K=1 /(1$ $+a \cdot \mathrm{dbh}$ ) (where $a=0.235 \pm 0.047 ; r^{2}=0.16$ ).

When Eq. 2 was applied to historical time series of hourly winter air temperatures, the predicted average buffering (predicted minimum winter phloem temperature - minimum winter air temperature) ranged from $\sim 1.0^{\circ}$ to $4.3^{\circ} \mathrm{C}$ as $K$ decreased from 0.299 to $0.066 \mathrm{~h}^{-1}$ (corresponding to trees from 10 to $60 \mathrm{~cm} \mathrm{dbh;} \mathrm{Fig.} \mathrm{4).}$ The frequency distributions of thermal buffering were approximately normally distributed, with standard deviations increasing from $0.5^{\circ}$ to $1.1^{\circ} \mathrm{C}$ as $K$ decreased. In Elkins, West Virginia, in the winter of 2002-2003, the predicted thermal buffering was $3-5^{\circ} \mathrm{C}$ higher than average (Fig. 4). This corresponded to an unusually brief cold bout on 18 January in which air temperatures went from $-5^{\circ}$ to $-25^{\circ} \mathrm{C}$ and then back to above $-5^{\circ} \mathrm{C}$ within 43 hours. Elkins was also the second highest site in our analysis at $594 \mathrm{~m}$ above sea level (a.s.1.). For most time series, the coldest night in the phloem was predicted to be the night of the coldest air temperature or the next

TABLE 1. Summary of thermal buffering in pine trees. The data shown are nine time series of air and phloem temperatures, and results from fitting a heat transfer model (Eq. 2) to each tree.

\begin{tabular}{|c|c|c|c|c|c|c|c|c|c|c|}
\hline \multirow[b]{3}{*}{ Origin } & \multirow[b]{3}{*}{$\begin{array}{l}\text { Pinus } \\
\text { species }\end{array}$} & \multirow[b]{3}{*}{$\begin{array}{l}\mathrm{dbh} \\
(\mathrm{cm})\end{array}$} & \multirow[b]{3}{*}{$\begin{array}{c}\text { Days of } \\
\text { data }\end{array}$} & \multirow[b]{3}{*}{$\begin{array}{l}\text { Recording } \\
\text { interval (h) }\end{array}$} & & & & \multicolumn{3}{|c|}{ Model fit from Eq. 2} \\
\hline & & & & & \multicolumn{3}{|c|}{ Average of $T_{\text {air }}-T_{\text {phloem }}\left({ }^{\circ} \mathrm{C}\right)$} & \multirow[b]{2}{*}{$K\left(\mathrm{~h}^{-1}\right)$} & \multicolumn{2}{|c|}{$\mathrm{RMSE} \dagger\left({ }^{\circ} \mathrm{C}\right)$} \\
\hline & & & & & $\begin{array}{l}\text { Daily } \\
\text { mean }\end{array}$ & $\begin{array}{c}\text { Daily } \\
\text { maxima }\end{array}$ & $\begin{array}{c}\text { Daily } \\
\text { minima }\end{array}$ & & $\begin{array}{l}\text { All } \\
\text { data }\end{array}$ & $\begin{array}{l}\text { Daily } \\
\text { minima }\end{array}$ \\
\hline New Jersey & P. rigida & 38 & 89 & 1 & 1.7 & 6 & -4 & 0.081 & 1.7 & 1.5 \\
\hline New Jersey & P. rigida & 42 & 89 & 1 & 1.5 & 4 & -1 & 0.245 & 1.5 & 1.1 \\
\hline Pennsylvania & P. strobus & 50 & 3 & 0.25 & -1.0 & 2 & -7 & 0.013 & 1.1 & 1.0 \\
\hline Mississippi & P. taeda & 36 & 36 & 1 & 1.2 & 3 & -1 & 0.139 & 0.8 & 0.6 \\
\hline Mississippi & P. taeda & 15 & 30 & 1 & 1.5 & 3 & 0 & 0.240 & 1.2 & 0.8 \\
\hline Mississippi & P. taeda & 38 & 30 & 1 & 2.0 & 5 & -1 & 0.076 & 0.6 & 0.6 \\
\hline Mississippi & P. taeda & 27 & 17 & 1 & 0.6 & 2 & -2 & 0.201 & 0.7 & 1.1 \\
\hline Mississippi & P. taeda & 17 & 18 & 1 & 1.6 & 3 & -1 & 0.159 & 1.0 & 0.7 \\
\hline Alabama & P. taeda & 18 & 61 & 1 & 1.1 & 3 & -1 & 0.116 & 1.0 & 1.0 \\
\hline
\end{tabular}

$\dagger$ Root mean square error. 


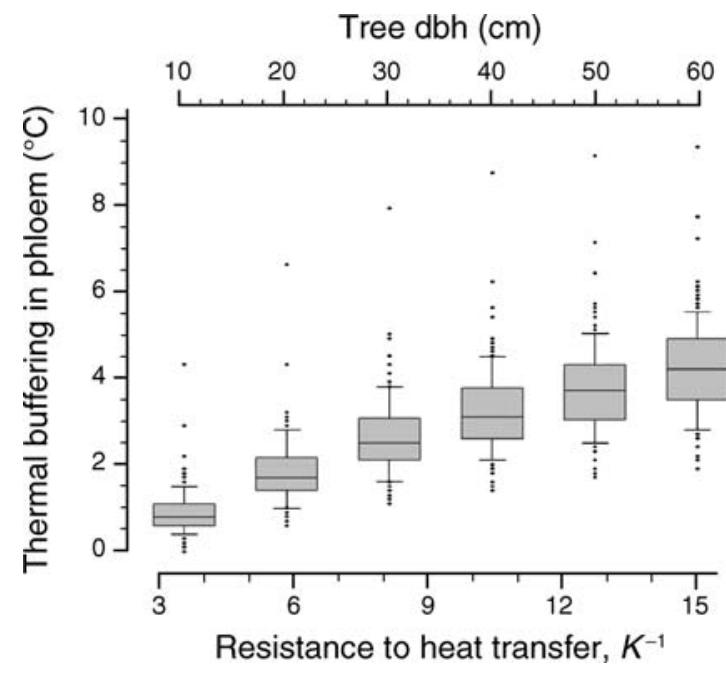

FIG. 4. Predicted thermal buffering in phloem based upon historical time series of winter air temperatures and a heat transfer model (Eq. 2). Climatic data were hourly air temperatures from 1 December to 28 February for 140 winters in the southeastern United States (3-7 winters $\times 25$ sites). Cooling constants $(K)$ correspond to typical pine trees with diameters of $10-60 \mathrm{~cm}(K=1 /(1+0.235 \times \mathrm{dbh})$. Thermal buffering was defined as the difference between minimum air temperature and predicted minimum phloem temperature (given $K$ ) during each winter record. Indicated are 10th, 25th, 50th, 75th, and 90th percentiles, and outliers. The upper outlier at all $K$ 's represents Elkin, West Virginia, in the winter of 20022003 (see Results: Phloem temperatures).

night (56-83\% of 140 time series for $K$ 's of $0.066-0.299$ $\mathrm{h}^{-1}$, respectively). Regression analyses indicated that thermal buffering $(B)$ was greatest in southerly latitudes and when $K$ was low (see Eq. 7; $P<0.0001$ for all coefficients, $r^{2}=0.63$, RMSE $=0.88^{\circ} \mathrm{C}$, delta AIC compared to the best simpler model $=42, n=840$ ):

$$
\begin{aligned}
B= & 54.16-2.62 \text { (latitude })+0.035{\text { (latitude })^{2}}^{2} \\
& +0.0015(\text { elevation })-36.62 K+62.83 K^{2} .
\end{aligned}
$$

Based on this regression, in a tree with $K=0.096 \mathrm{~h}^{-1}$ $(\sim 40 \mathrm{~cm} \mathrm{dbh}), B=4.9^{\circ}$ to $3.6^{\circ} \mathrm{C}$ at $30.75^{\circ}$ vs. $35.75^{\circ} \mathrm{N}$, and by $3.5^{\circ}$ to $4.3^{\circ} \mathrm{C}$ at 5 vs. $600 \mathrm{~m}$ a.s.l.

\section{Cold tolerance of $\mathrm{D}$. frontalis in New Jersey}

The mean supercooling point of southern pine beetle adults collected in November from New Jersey was $-9.7^{\circ} \pm 2.7^{\circ} \mathrm{C}($ mean $\pm \mathrm{SD})(n=27)$, significantly lower than in adult beetles collected at the same time in Alabama: $-7.2^{\circ} \pm 1.6^{\circ} \mathrm{C}(n=25)\left(t_{50}=4.18, P=0.0002\right)$. However, the cold tolerance of even the New Jersey adults was actually less than the values previously reported by Lombardero et al. (2000) and used by Ungerer et al. (1999) for modeling winter mortality. As previously reported, freezing was invariably fatal, as no individuals showed any sign of life following freezing.

The only life stage that appeared to be successfully overwintering in New Jersey during 2004-2005 was late fourth instars (prepupae) in the outer bark (see Plate 1). Although we found a few adults and younger larvae, most of them were dead (Table 2). Given this result, all additional physiological measurements were conducted on prepupae. The supercooling point for prepupae $\left(\right.$ mean $\pm \mathrm{SD}=-14.6^{\circ} \pm 3.9^{\circ} \mathrm{C}$, minimum $=-19.9^{\circ} \mathrm{C}, n$ $=298$ ) was much lower than that for adults collected in November, and lower than any previously published measurements on southern pine beetle in any life stage (Fig. 5). Although fourth instars resisted freezing to a lower temperature, they still died when freezing occurred. There was no detectable effect of cooling rate on supercooling temperatures of fourth instars $\left(t_{296}=0.66\right.$, $P=0.51)$.

Bark samples containing prepupae from New Jersey produced large numbers of apparently healthy adults after exposure to one night of temperatures at $-15.3^{\circ} \mathrm{C}$. This proved the ability of $D$. frontalis to survive temperatures previously thought to produce nearly complete mortality (Ungerer et al. 1999). There were high levels of emergence from both treated and control bark. Emergence peaked at $\sim 21$ days, with totals of 193 and 138 adult beetles, respectively. It was not possible to estimate proportional mortality in these bark samples, but dissection revealed some dead fourth instars in both samples. Out of 100 untreated individuals (prepuae) that were removed from the bark and placed in vials, 23 successfully developed to adults, 5 developed to callow adults before dying, and 72 died as fourth instars.

The frequency distribution of supercooling points was generally a reliable predictor of the probability of survival given exposure to any specific temperature (Table 3). In three of four experiments, there was an excellent match between observed and expected survival. In the fourth experiment, with exposure to $-13.7^{\circ} \mathrm{C}$, observed survival (90\%) was significantly higher than expected (73\%). The average supercooling point of those fourth instars that survived the $-17.4^{\circ} \mathrm{C}$ treatment $\left(-18.60^{\circ} \pm 0.9^{\circ} \mathrm{C}, n=16\right)$ was much lower and less variable than that of an unselected population $\left(t_{312}=\right.$ 4.04, $P<0.0001)$. Overall, results supported the premise (implicit in our application of Eq. 5) that supercooling points in $D$. frontalis usually represent the lower lethal temperature. This is common in (freeze-susceptible)

TABLE 2. Life stages present in a southern pine beetle population near Cape May Courthouse, New Jersey, in

\begin{tabular}{|c|c|c|c|c|}
\hline \multirow[b]{2}{*}{ Life stage } & \multicolumn{2}{|c|}{ All individuals } & \multicolumn{2}{|c|}{ Average across trees } \\
\hline & $n$ & $\begin{array}{c}\text { Alive } \\
(\%)\end{array}$ & $n_{\text {trees }}$ & $\begin{array}{l}\text { Average } \\
\text { alive (\%) }\end{array}$ \\
\hline Eggs & 0 & $\cdots$ & 0 & $\cdots$ \\
\hline Larvae in phloem & 26 & 7.7 & 6 & 5.6 \\
\hline Larvae in outer bark & 1562 & 99.8 & 8 & 99.9 \\
\hline Pupae & 0 & $\ldots$ & 0 & $\ldots$ \\
\hline Adults & 103 & 0 & 10 & 0 \\
\hline
\end{tabular}
February 2005. 


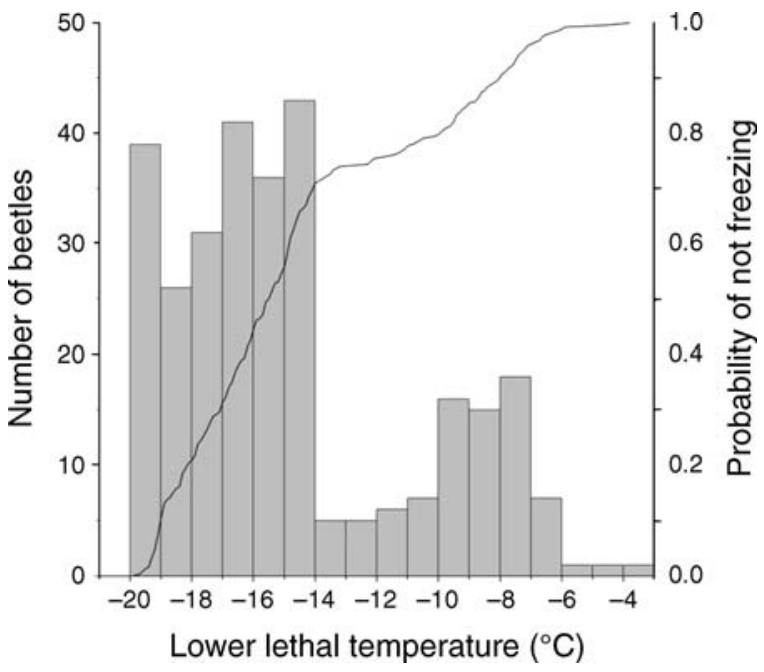

FIG. 5. Frequency distribution of supercooling points of late fourth-instar larvae from New Jersey measured during February 2005. The line indicates the probability of not freezing.

insects, but not universal (Bale 2002, Renault et al. 2002, Carrillo et al. 2005b).

\section{Population growth}

Interannual growth rates of $D$. frontalis, measured from trap captures, averaged $-0.19 \pm 1.71$ beetles $\cdot$ beetle ${ }^{-1} \cdot \mathrm{yr}^{-1}$ (mean \pm SD). As predicted by Ungerer et al (1999), these rates were more likely to be negative following a winter in which the minimum air temperature dropped below $-16^{\circ} \mathrm{C}\left(72 \%\right.$ of 96 vs. $54 \%$ of $1108 ; \chi^{2}=10.9, \mathrm{df}=1, P$ $<0.001$ ). Linear threshold regression revealed a pattern of decreasing interannual growth rates when minimum winter air temperatures dropped below $c \pm \mathrm{SE}=-12.5^{\circ}$ $\pm 1.2^{\circ} \mathrm{C}$, the threshold temperature in Eq. $4\left(F_{2,1436}=11.2\right.$, $P<0.001$; delta AIC compared to the linear nonthreshold model $=9.8$ ). As predicted, the threshold $c$ was close to the lower lethal temperatures that Lombardero et al. (2000) reported from physiological studies. The slope $(a \pm \mathrm{SE}=$ $0.122 \pm 0.04)$ was significantly different from zero $\left(t_{1436}=\right.$ 3.37, $P<0.001)$. The intercept, representing average population growth in the absence of lethally cold temperatures, was near $0(b \pm \mathrm{SE}=-0.11 \pm 0.05)$. Although the regression model (Eq. 3) was highly significant, it explained $<2 \%$ of the total variation in population growth rate $\left(r^{2}=0.015\right)$, indicating the importance of other factors. Quantile regression models (Eq. 4) were significant for six of the nine deciles (Table 4). Slopes were always positive $(a>0)$ indicating an increase in growth rate with minimum winter air temperature for all deciles, and thresholds were in the range $-13.2^{\circ}$ to $-10.8^{\circ} \mathrm{C}$. Neither parameter was systematically related to decile rank. Contrary to the predictions of Ungerer et al. (1999), there were some cases of positive interannual growth rates even when minimum winter air temperature dropped below $-16^{\circ} \mathrm{C}$. Most notably, there were growth rates of $3.15,4.25$, and 0.897 beetles beetle ${ }^{-1} \cdot \mathrm{yr}^{-1}$ in the Ocoee Ranger District, Tennessee, from 1995 to 1996 and in the Nolichucky Ranger District, Tenneesse, from 1992 to 1993 and 1995 to 1996 , even though the estimated minimum winter air temperatures were $-20.7^{\circ},-18.0^{\circ}$, and $-28.3^{\circ} \mathrm{C}$, respectively (Fig. 6).

Interannual growth rates in the number of $D$. frontalis infestations (spots) also were more likely to be negative following a winter in which the minimum winter air temperature dropped below $-16^{\circ} \mathrm{C}$ ( $74 \%$ of 85 vs. $55 \%$ of 968; $\chi^{2}=11.1$, df $=1, P<0.0001$; Fig. 6b). As in analyses of trap capture data, the linear threshold regression from spot data was highly significant and qualitatively consistent with theoretical expectations, but had very low explanatory power overall: $r^{2}=0.011$, $F_{2,1501}=8.60, P=0.0002$ (delta AIC compared to linear nonthreshold model $=38.3$ ); slope $\pm \mathrm{SE}=0.103 \pm 0.03$ $\left(t_{1501}=3.01, P=0.003\right)$, when minimum winter air temperatures $\pm \mathrm{SE}$ dropped below $-11.6^{\circ} \pm 1.48^{\circ} \mathrm{C}$; intercept $\pm \mathrm{SE}=-0.14 \pm 0.06\left(t_{1501}=2.25, P=0.02\right)$. Quantile regression was significant for five of the nine deciles, with positive slopes and thresholds in the range of -13.1 to -9.2 (Table 4). Again, slopes and thresholds were not systematically related to decile rank. As with trappings, there were cases of positive interannual growth in the number of spots, even when minimum winter air temperature dropped below $-16^{\circ} \mathrm{C}$. Most notably, there were growth rates of 1.35 and 1.61 spots. $\operatorname{spot}^{-1} \cdot \mathrm{yr}^{-1}$ in the Grandfather Ranger District, North Carolina, from 1993 to 1994, and in Oktibbeha, Mississippi, from 1989 to 1990, even though the estimated minimum winter air temperatures were $-22.1^{\circ} \mathrm{C}$ and $-22.4^{\circ} \mathrm{C}$, respectively (Fig. $6 \mathrm{~b}$ ).

Interannual growth rates of the bark beetle predator, T. dubius, were about as variable in space and time as those of $D$. frontalis (mean $\pm \mathrm{SD}=-0.01 \pm 1.14 \mathrm{yr}^{-1}$ ). Linear threshold regression suggested a weak pattern of decreasing interannual growth rates $\left(r^{2}=0.005 ; F_{2,1436}=\right.$ 3.90; $P=0.02$, delta AIC compared to linear nonthreshold model $=5.8$; data not shown), with slope $\pm \mathrm{SE}$ $=0.064 \pm 0.03\left(t_{1436}=1.89, P=0.06\right)$ when minimum winter air temperatures dropped below $c \pm \mathrm{SE}=-14.0$ $\pm 2.0^{\circ} \mathrm{C}$, and an intercept $\pm \mathrm{SE}$ of $0.014 \pm 0.032\left(t_{1436}=\right.$ $0.43, P=0.67)$.

TABLE 3. Survival of fourth-instar larvae from New Jersey following exposure to low temperature.

\begin{tabular}{crccrcc}
\hline \hline & \multicolumn{4}{c}{ Survival (\%) } & & \\
\cline { 3 - 4 } Treatment $\left({ }^{\circ} \mathrm{C}\right)$ & $n$ & Observed & Expected & $\chi^{2}$ & $P$ \\
\hline-13.67 & 100 & 90 & 73 & 15.36 & $<0.0001$ \\
-15.64 & 83 & 58 & 49 & 2.43 & 0.12 \\
-17.36 & 100 & 26 & 29 & 0.44 & 0.51 \\
-19.66 & 100 & 0 & 1.3 & 1.36 & 0.24
\end{tabular}

Note: Expected survival is the percentage of individuals that do not freeze based upon the distribution of supercooling points. 
TABLE 4. Summary of decile linear threshold regression for population growth rate of $D$. frontalis as a function of minimum winter air temperature (Eq. 4).

\begin{tabular}{|c|c|c|c|c|c|c|c|c|c|c|}
\hline \multirow{2}{*}{$\begin{array}{l}\text { Abundance } \\
\text { units }\end{array}$} & \multirow{2}{*}{$\begin{array}{c}\text { Model } \\
\text { parameter }\end{array}$} & \multicolumn{9}{|c|}{ Decile } \\
\hline & & 10 & 20 & 30 & 40 & 50 & 60 & 70 & 80 & 90 \\
\hline \multirow[t]{4}{*}{ Trap captures } & Slope, $a\left(\right.$ rate $\left./{ }^{\circ} \mathrm{C}\right)$ & 0.143 & 0.173 & 0.19 & 0.152 & 0.123 & 0.13 & 0.107 & 0.105 & 0.129 \\
\hline & Intercept, $b$ (rate) & -2.41 & -1.40 & -0.80 & -0.26 & -0.01 & 0.17 & 0.46 & 1.09 & 2.16 \\
\hline & Threshold, $c\left({ }^{\circ} \mathrm{C}\right)$ & -13.2 & -12.4 & -12.6 & -10.8 & -11.1 & -13.1 & -13.2 & -12.4 & -12.4 \\
\hline & $F_{2,37}$ & 2.2 & $8.5^{*}$ & $12.0^{*}$ & $23.4^{*}$ & $23.4^{*}$ & $11.0^{*}$ & $3.5^{*}$ & 2.3 & 2.4 \\
\hline \multirow[t]{4}{*}{ "Spots" per forest } & Slope, $a\left(\right.$ rate $\left./{ }^{\circ} \mathrm{C}\right)$ & 0.049 & 0.091 & 0.189 & 0.147 & 0.093 & 0.07 & 0.09 & 0.156 & 0.205 \\
\hline & Intercept, $b$ (rate) & -2.95 & -1.53 & -0.73 & -0.26 & -0.04 & 0.10 & 0.50 & 1.19 & 2.50 \\
\hline & Threshold, $c\left({ }^{\circ} \mathrm{C}\right)$ & -9.8 & -9.2 & -12.4 & -12.9 & -13.1 & -12.7 & -12.4 & -12.4 & -12.4 \\
\hline & $F_{2,37}$ & 0.5 & $3.4^{*}$ & $7.6^{*}$ & $6.6^{*}$ & $12.1^{*}$ & $4.7 *$ & 1.7 & 2.3 & 2.5 \\
\hline
\end{tabular}

Note: The table matches data in Fig. 6.

$* P<0.05$.

\section{Theoretical models relating climatic data to $\mathrm{D}$. frontalis population dynamics}

Fig. 7 compares observed patterns in D. frontalis population dynamics to alternative theoretical models for the effects of minimum winter air temperature. Scenario 1, following Ungerer et al. (1999), predicted that population growth rates would decrease sharply as minimum winter air temperature decreased from $-10^{\circ}$ to $-15^{\circ} \mathrm{C}$. The addition of regional variability in minimum winter air temperature (scenario 2) had almost no effect on the expected probability of not freezing, and is not shown. Scenario 3, with the addition of better estimates of thermal buffering, lowered the temperature of $50 \%$ mortality from $-11.7^{\circ}$ to $-13^{\circ} \mathrm{C}$, but still overestimated the sensitivity of population growth rates to low temperatures (compare scenario 3 to data, Fig. 7). Scenario 4, with the addition of a cold-tolerant life stage (prepupae; Fig. 5), and a concentration of overwintering individuals within that life stage (matching Table 2), shifted the expected survival function by $4.4^{\circ} \mathrm{C}$, and provided a reasonably satisfying fit with the empirical decline in average population growth rates at low temperatures (Fig. 7).

\section{Discussion}

\section{Prediction of experienced temperatures}

Estimates of minimum winter air temperature in study forests (using NOAA data) were adequate for modeling the effects of winter air temperatures on $D$. frontalis. The addition of unexplained spatial variation in minimum temperature had an inconsequential effect on predicted mortality patterns. That is, the RMSEs for Eq. 1 were sufficiently modest $\left(1.3^{\circ}-1.8^{\circ} \mathrm{C}\right)$ that scenario 2 was nearly identical to scenario 1 using Eq. 5. The prediction of experienced temperatures requires the additional step of relating air temperature to temperature in the phloem, where southern pine beetles spend most of their lives (Payne 1980). A model based on Newtonian cooling (Eq. 2) permits predictions of phloem temperature given estimates of $K$ and knowledge of the time course of air temperatures during winter cold bouts (Fig. 2, Table 1). Eq. 2 also provides a mechanistic description of heat transfer, and suggested a general means for incorporating effects of tree size (by modeling $K$ as a function of tree size).

Application of Eq. 2 to historical time series of hourly winter temperatures provided a general description of thermal buffering of minimum temperatures in pine phloem (Fig. 4). Previously published estimates were as disparate as Beal (1934) and Bolstad et al. (1997), who reported thermal buffering of minimum temperatures in pine phloem of up to $12^{\circ} \mathrm{C}$ vs. $<1^{\circ} \mathrm{C}$. Beal deliberately measured large trees with thick bark (up to $5 \mathrm{~cm}$ ), and presumably with low $K$ 's, during a brief but extreme cold bout (air temperatures from $-6^{\circ}$ to $-32^{\circ}$ to $-12^{\circ} \mathrm{C}$ within 35 hours). Our analyses of 140 winter temperature series from the southeastern United States did not reveal a single occasion where so much buffering would have been expected (Fig. 4). However, the predicted buffer was more than previously assumed by Ungerer et al. (1999): average of $1.5^{\circ}-3.9^{\circ} \mathrm{C}$ (maximum of $9.2^{\circ} \mathrm{C}$ ) for trees of $\sim 20-50 \mathrm{~cm}$ dbh. With these new predictions of thermal buffering experienced by $D$. frontalis, the air temperature required to produce $50 \%$ mortality shifted downward by $1.3^{\circ} \mathrm{C}$ (scenario 3 vs. scenario 1 in Fig. 7). Eq. 2, as simple as it is, seems to work well in the closedcanopy pine forests that are typically inhabited by $D$. frontalis in the southeastern United States (Table 1). Eq. 2 assumes no other heat source and would not work without modification in trees that experience significant warming from solar radiation (Bolstad et al. 1997).

\section{Prediction of physiological effects of temperature}

Field and laboratory studies of a northern $D$. frontalis population provided important new knowledge by showing that prepupae were more cold tolerant (by $>3.5^{\circ} \mathrm{C}$ ) than pupae, adults, and feeding larvae, and that the winter life stage structure was strongly biased toward this most cold-tolerant life stage. This was not an artifact of differential mortality from cold exposure prior to collection, because dead individuals of other life stages were not found, even though winter temperatures preserved them well enough to be easily observed in our sampling. The predominance of prepupae appears to be an example of adaptive seasonality (sensu Logan and 


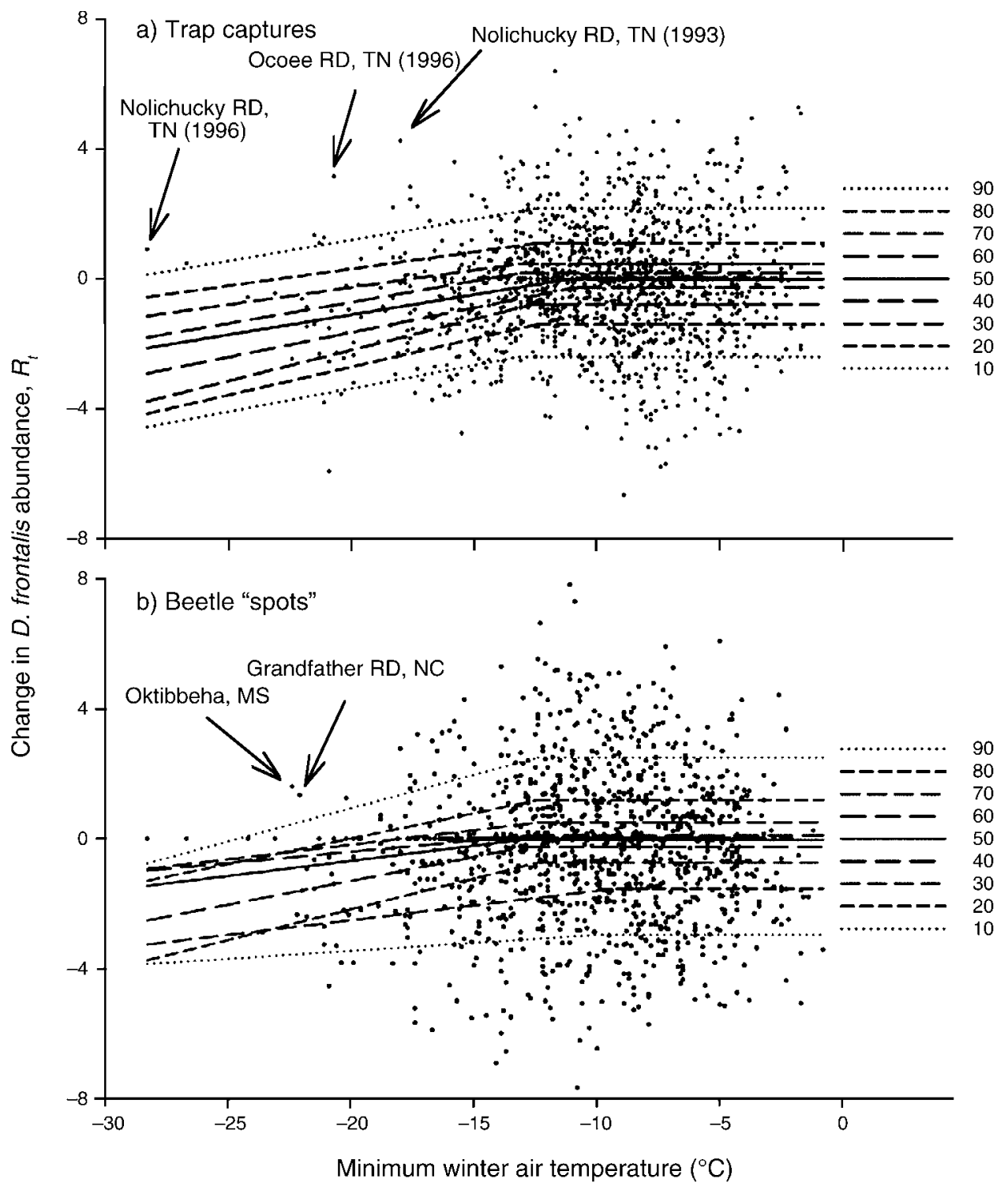

FIG. 6. The relationship between minimum winter air temperature and interannual changes in Dendroctonus frontalis abundance as measured by (a) pheromone-based trapping in the spring and (b) the number of discrete local infestations (beetle "spots") detected in systematic aerial surveys. Lines show threshold linear regression for each decile (10-90) of beetle population growth (Table 4). Data points specifically identified (arrows) are from the Nolichucky, Ocoee, and Grandfather Ranger Districts (RD), and a field site in Oktibbeha, Mississippi.

Bentz 1999), where there is a favorable match of life stage to season (even without diapause). The addition of a cold-tolerant life stage (prepupae) and adaptive seasonality to Eq. 5 had a marked effect on expected winter mortality as a function of minimum winter air temperature, and contributed more to a good fit between theoretical predictions and empirical population growth rates than improved estimates of microsite temperatures (Fig. 7).

Further studies of seasonality in D. frontalis life stage distributions would be valuable, particularly in the northern extremes of the species' range. Thatcher and Barry (1982) wrote "The southern pine beetle over- winters ... in the egg, larval, pupal, or adult stages." Thatcher (1967) reported the presence of all life stages (from egg to ovipositing adult) during December of three winters in east Texas (although with a diminution of eggs by mid-February). However, observers in the mountains of North Carolina have reported that most D. frontalis there spend the coldest parts of the winter as larvae (Beal 1933, McClelland and Hain 1979 [without specifying the proportion of larvae that were feeding in the phloem vs. preparing to pupate in the outer bark]). We hypothesize that other northern populations of $D$. frontalis, in other years, also tend to overwinter as prepupae. This could be a purely phenotypic result of 


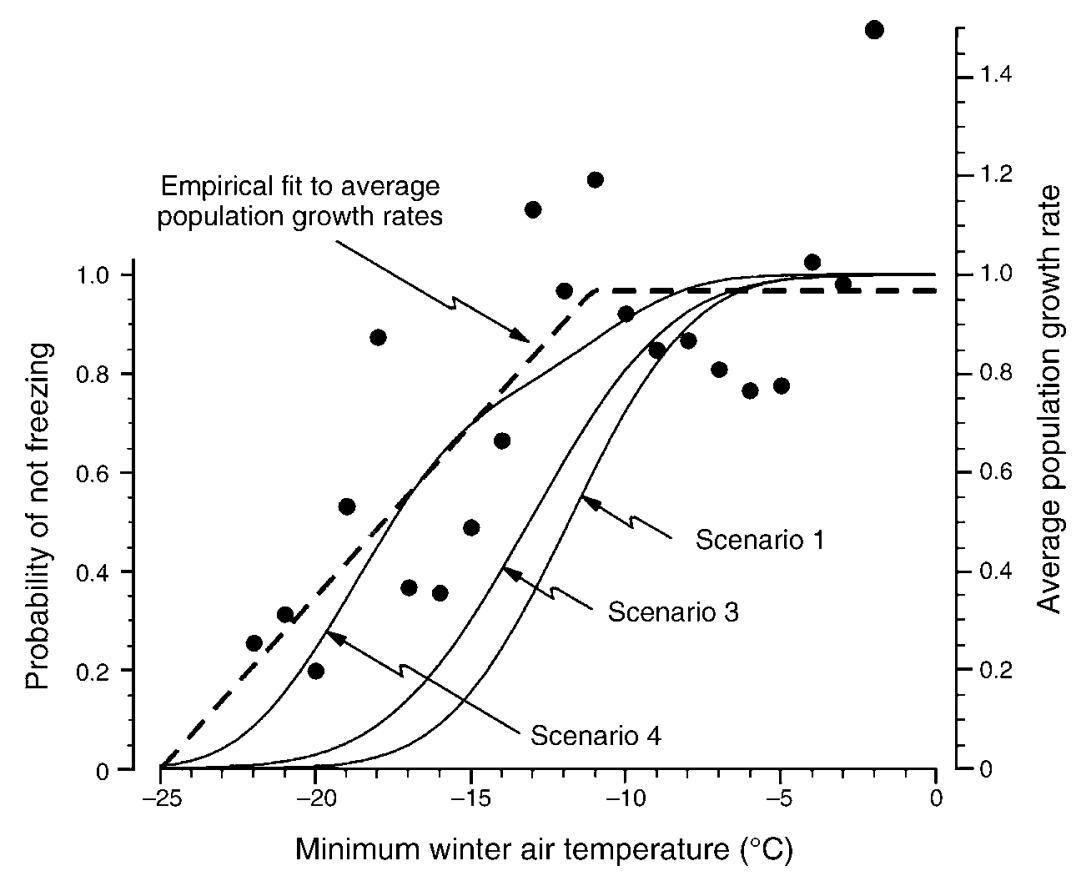

FIG. 7. Theoretical probability of not freezing (solid lines) from Eq. 5 under three scenarios: Scenario 1, following Ungerer et al. (1999) with thermal buffering of $1^{\circ} \mathrm{C}$; Scenario 3, scenario 1 plus local spatial variation in air temperatures and a frequency distribution of thermal buffering as in Fig. 4; Scenario 4, scenario 3 plus recognition of cold-tolerant prepupae as in Fig. 5 and Table 2. For comparison, points show empirical average population growth rate for each temperature $\left( \pm 0.5^{\circ} \mathrm{C}\right)$ calculated from data in Fig. 6a and fit with Eq. 4 (dashed line). Sample sizes for population growth rates, from $-22^{\circ}$ to $-2^{\circ} \mathrm{C}$, respectively, were 6 , 13, 12, 5, 24, 30, 48, 56, 74, 90, 141, 110, 139, 153, 183, 166, 127, 123, 84, 38, and 20.

differences among life stages in their developmental responses to temperature (Powell et al. 2000), or could involve genetic differences among populations inhabiting different climatic regions (Ayres and Scriber 1994, Bentz et al. 2001). The tendency to overwinter in a coldtolerant life stage could be a coincidence rather than an adaptation. For example, constraints of holometabolous development might dictate that molting to pupae is slowed more by low temperatures than is growing through the last larval instar (Ayres and Scriber 1994), and prepupae might be more cold tolerant just because they have no food in their gut. If winter temperatures tend to synchronize the age structure for any reason, northern populations would tend to have one or another life stage predominating throughout the year, because there are fewer generations per year for convergence on a stable age distribution.

The mechanistic basis for enhanced cold tolerance in prepupae remains unknown, but might include synthesis of cryoprotectants and/or the elimination of nucleating agents in the gut after cessation of feeding (Beal 1933, Bale 2002). It cannot be explained by the physicochemical characteristics of outer bark vs. phloem (Beal 1933), because the differences persist when the insects are removed from the outer bark. Even with the recognition of a cold-tolerant life stage, and adaptive seasonality, the cold tolerance of $D$. frontalis is on the low end for bark beetles. (Of 16 species that have been studied, seven survive temperatures of $-25^{\circ} \mathrm{C}$ or less, and none is less cold tolerant than D. frontalis [Somme 1982, Miller and Werner 1987, Bentz and Mullins 1999, Lombardero et al. 2000].) Since northern populations of $D$. frontalis sometimes experience high mortality from low temperatures, it is somewhat surprising that $D$. frontalis has not evolved greater cold tolerance. Adaptation of northern populations could be constrained by gene flow from southern populations, especially if there are trade-offs between cold tolerance and the possibility for continued development of beetles during mild winter days.

\section{Population growth}

Results permitted evaluation of a process-based model of climatic effects on $D$. frontalis populations. The qualitative concordance between model predictions and independent measurements of population fluctuations indicate that $D$. frontalis populations can be influenced by freezing during winter cold bouts. The empirically fit threshold values for demographic effects ( $c$ is approximately $-12^{\circ} \mathrm{C}$; Eq. 4, Figs. 6-7) were a reasonable match with independent physiological measurements (Beal 1933, Lombardero et al. 2000, this study) and historical observations of notable winter mortality (reviewed in Ungerer et al. 1999). Furthermore, the threshold model (Eq. 4), which was derived from a model of mortality from freezing, was better supported by the data than an alternative linear model. Finally, there was a reasonably good fit between average 

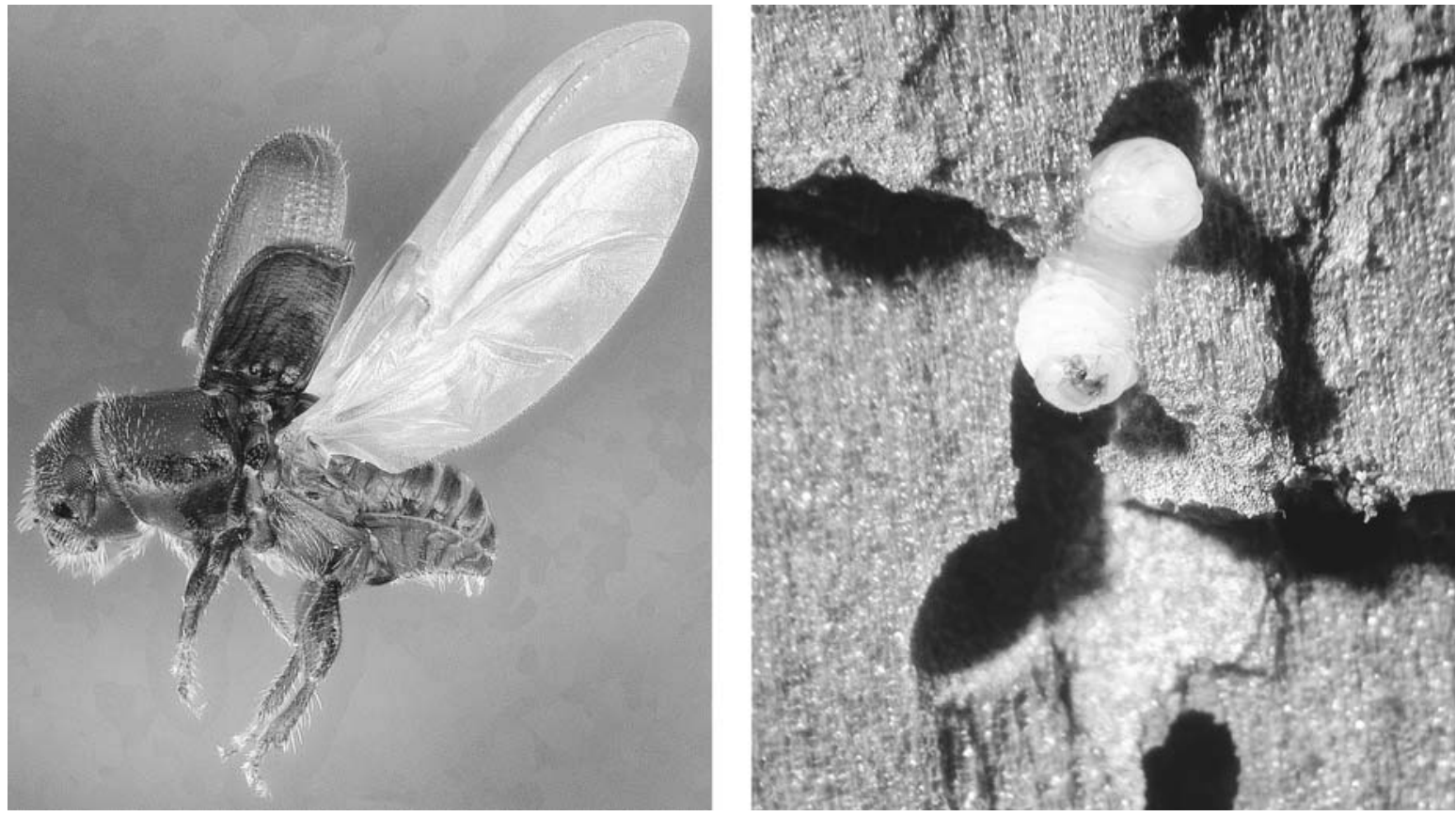

Plate 1. (Left) adult and (right) prepupa of the southern pine beetle, Dendroctonus frontalis. Photo credits: Erich Vallery, USDA Forest Service, and J. K. Trần, respectively.

population growth rates and the predictions of a theoretical model that was independently derived and parameterized based on susceptibility to freezing (scenario 4 in Fig. 7). The theoretical model (Eq. 5) has been generally validated at all three steps of a generalized approach for modeling climatic effects on population dynamics (see Introduction).

However, knowledge of minimum winter air temperature explained only a scant $1.5 \%$ of the total variation in interannual growth rates of historical time series of $D$. frontalis abundance. Winter temperature is clearly only a minor driver of southern pine beetle population dynamics over much of the historical range of $D$. frontalis, where minimum temperatures rarely reach the supercooling point of beetles. (The estimated minimum winter air temperature was more than $-12^{\circ} \mathrm{C}$ in $75 \%$ of 1440 winters in the $D$. frontalis population monitoring program.) Even when temperatures were cold enough so that freezing mortality was expected, there was still high unexplained variance in $D$. frontalis population growth, and there were several cases of positive population growth rates even with air temperatures below $-20^{\circ} \mathrm{C}$ (Fig. 6; see also Ragenovich 1980). We attribute most of the high variance in population growth rate to demographic processes during the 3-7 beetle generations that occur after population sampling in one spring and before the subsequent winter. Some of the dynamic forces known to influence $D$. frontalis populations include density dependence, predators, host suitability, community interactions with symbiotic fungi, pest suppression programs, adverse summer temperatures, and competition with other phloem-feeding insects (Flamm et al. 1993, Lorio 1993, Reeve et al. 1998, Turchin et al. 1999, Clarke et al. 2000, Clarke and Billings 2003, Hofstetter et al. 2006). Other sources of residual variation probably include sampling error in annual population estimates and variation in thermal buffering (Fig. 4; Eq. 7).

Although population growth rates are highly variable for reasons unrelated to winter temperatures, there appear to be meaningful effects of winter temperatures on northern populations of beetles. Ungerer et al. (1999) predicted that an increase of $3^{\circ} \mathrm{C}$ would permit the occurrence of outbreaks $\sim 178 \mathrm{~km}$ farther north than in historical times. In fact, average minimum winter air temperatures have increased by just over $3^{\circ} \mathrm{C}$ since 1960 (Fig. 2). From 1960 into the 1990s, D. frontalis outbreaks were rare or nonexistent north of North Carolina and Tennessee. In the last decade, there have been outbreaks in Kentucky, Delaware, Maryland, Virginia, New Jersey, and even Ohio. Outbreaks in New Jersey started in 2001 and have continued to occur. From 1960 to 1996, minimum winter air temperatures near the current New Jersey infestations averaged $-16^{\circ} \mathrm{C}$, and there were 10 winters when the minimum air temperature dropped to at least $-18^{\circ} \mathrm{C}$ (sufficient to halve population growth rate; Fig. 7). Since 1996, minimum winter air temperatures have averaged $-13^{\circ} \mathrm{C}$ and have not dropped below $-16^{\circ} \mathrm{C}$ (based on three climate stations: Atlantic City 1, Atlantic City 2, and Millville). The New Jersey infestations are $\sim 292 \mathrm{~km}$ (200 km north) from the nearest forests where there were 
systematic records of $D$. frontalis activity from 1960 to 1996 (near Richmond, Virginia [Price et al. 1997]). Foresters in Maryland have been monitoring $D$. frontalis since 1988. Foresters in Delaware and New Jersey joined the monitoring program in 2001 and 2002, respectively. Ohio participated only in 2001. The recent northern expansion of $D$. frontalis infestations is about as predicted by Ungerer et al. (1999) for an increase of $3^{\circ} \mathrm{C}$ in minimum winter air temperatures.

A weakness in our understanding of climatic effects on the distribution of $D$. frontalis is that we still lack models that can predict the details of range expansions. (For example, Eq. 5 could not have predicted that there would be outbreaks near Millville, New Jersey, beginning in 2001.) Presumably, range expansions involve immigration, as well as survival and reproduction of beetles when they are present. Models such as Eq. 5 could be expanded to include immigration, but at present we do not know whether the dispersal of $D$. frontalis into unoccupied forests is as predictable as diffusion, or if it involves occasional stochastic movements over large distances (Turchin and Thoeny 1993, Sharov and Liebhold 1998, Byers 2000, Cronin et al. 2000, Safranyik and Carroll 2005). Alternatively, dispersal might not be very important if northern outbreaks of beetles are mainly due to favorable conditions for resident populations that are below detection levels.

\section{Conclusions}

Some of our results could benefit forest managers who seek reliable short-term predictions of $D$. frontalis abundance. If the coldest night of the winter does not drop below $-12^{\circ} \mathrm{C}$, there are no obvious effects of low temperatures on $D$. frontalis populations, nor any apparent reason from physiological studies to expect an effect. If air temperatures drop below $-16^{\circ} \mathrm{C}$, populations are likely to decline (probability of decline $\sim 65 \%$ ). If temperatures reach $-20^{\circ} \mathrm{C}$, populations probably will decline (probability $\sim 80 \%$ ). Following any winters when the minimum air temperature goes below $-16{ }^{\circ} \mathrm{C}$, it will be unlikely that an epidemic of $D$. frontalis will arise from an endemic population (the occurrence would require improbably high growth rates). The climatic parameter most relevant to the winter survival of $D$. frontalis is the minimum temperature on the coldest night. The air temperature required to produce $50 \%$ beetle mortality ranges from about $-12^{\circ}$ to $-16^{\circ} \mathrm{C}$ depending upon life stage structure, the size of the trees that are infested, and the duration of the cold bout (Figs. 4 and 7). The single most valuable predictor of beetle abundance this year is beetle abundance last year (Billings 1988), but our study indicates that readily accessible climate data can sometimes allow for better predictions than would be possible with population monitoring alone.

D. frontalis can be added to the list of forest pests that have recently been generating large to massive disturbances in northern and high-altitude ecosystems where they were previously rare or absent. Other notable examples include the mountain pine beetle ( $D$. ponderosae) in western North America, the spruce beetle (D. rufipennis) in Alaska, and the pine processionary moth (Thaumetopoea pityocampa, Notodontidae) in the Mediterranean region (Logan et al. 2003, Carroll et al. 2004, Battisti et al. 2005). In all of these cases, there is evidence that climatic warming trends have permitted or triggered the changes. If the current global warming trend continues (Moberg et al. 2005, Oerlemans 2005), forest managers will likely be challenged by numerous novel pest problems for which there are no well-tested responses and only a limited basis for predicting the ecosystem consequences of not responding (Ayres and Lombardero 2000, Dale et al. 2001, Volney and Hirsch 2005).

As early as 1899 , A. D. Hopkins hypothesized that interannual variability in minimum winter temperatures influenced the population dynamics of $D$. frontalis (Beal 1933). The hypothesis that climate is a driver of animal population dynamics is much older (Anonymous 1665). The general approaches that have been used to evaluate this hypothesis include observations of natural fluctuations with reference to climatic conditions, physiological measurements, phenomenological models that screen for relationships between climate and population dynamics, transplant experiments, and mechanistic (process-based) models that predict population fluctuations based on hypothesized physiological effects of specific climatic drivers (e.g., Beal 1933, Davidson and Andrewartha 1948, Turchin et al. 1991, Pearson and Dawson 2003, Crozier 2004, Karban and Strauss 2004, Battisti et al. 2005). Together, Eqs. 1, 2, and 5 are an example of the last category. This model is general enough to be applied (with modified parameters) to other species in other systems where there are hypothesized effects of climatic extremes (warm or cold) on mortality. The model would have to be expanded to allow for cases where the physiological effects are more graded than survival (e.g., changes in development rates) or where the focal physiological process integrates climatic conditions over a period of time (e.g., if temperatures prior to a cold bout influence cold tolerance [Bentz and Mullins 1999, Chen and Kang 2005]). Other reasonably well-validated, process-based models have been developed to predict population dynamics as a function of climate for an assortment of taxa (Jenouvrier et al. 2003, Jacobson et al. 2004, Yonow et al. 2004, Altwegg et al. 2005, Carillo et al. 2005a, b, Edmunds 2005, Lloyd et al. 2005, Vucetich et al. 2005), but these are mostly recent and surprisingly few. The further development and testing of such models will contribute to the synthesis of physiological and population ecology, and aid in assessing the ecological consequences of climatic warming trends (Stenseth et al. 2002, Walther et al. 2002, Parmesan and Yohe 2003, Root et al. 2003; Reynolds et al., in press).

\section{ACKNOWLEDGMENTS}

This research was made possible by the many cooperators who participate in the southern pine beetle spring trapping program, by the Texas Forest Service for annually compiling 
data on southern pine beetle trap catches and infestations detected from across the southeastern United States, and the work of USFS Forest Health in Region 8 in developing and maintaining the Southern Pine Beetle Information System (SPBIS). Vital support was provided by the staff of the Oakmulgee Ranger District in Alabama, the Chickasawhay Ranger District in Mississippi, and the Forest Health Division of the New Jersey Forest Service. Ankit Rastogi and Ben Ayres processed climate data. Thanks to Bruce Ayres, Barbara Bentz, Nick Friedenberg, Dan Herms, Maria Lombardero, Sharon Martinson, Rebecca Smyth, and Lizzie Wolkovich for comments and discussion. Funding was provided by NSF DEB0316522, a cooperative agreement with the Southern Research Station, and the Academy of Finland (grants Nos. 51413 and 54379).

\section{Literature Cited}

Aanes, R., B. E. Sæther, and N. A. Oritsland. 2000. Fluctuations of an introduced population of Svalbard reindeer: the effects of density dependence and climatic variation. Ecography 23:437-443.

Aars, J., and R. A. Ims. 2002. Intrinsic and climatic determinants of population demography: the winter dynamics of tundra voles. Ecology 83:3449-3456.

Ahumada, J. A., D. Lapointe, and M. D. Samuel. 2004. Modeling the population dynamics of Culex quinquefasciatus (Diptera: Culicidae), along an elevational gradient in Hawaii. Journal of Medical Entomology 41:1157-1170.

Altwegg, R., S. Dummermuth, B. R. Anholt, and T. Flatt. 2005. Winter weather affects asp viper, Vipera aspis, population dynamics through susceptible juveniles. Oikos 110:55-66.

Anonymous. 1665. Some observations of swarms of strange insects, and the mischiefs done by them. Philosophical Transactions 1:137-138.

Ayres, M. P., and M. J. Lombardero. 2000. Assessing the consequences of climate change for forest herbivores and pathogens. Science of the Total Environment 262:263-286.

Ayres, M. P., and J. M. Scriber. 1994. Local adaptation to regional climates in Papilio canadensis (Lepidoptera: Papilionidae). Ecological Monographs 64:465-482.

Baldwin, V. C., Jr., and D. P. Feduccia. 1987. Loblolly pine growth and yield prediction for managed West Gulf plantations. Southern Forest Experiment Station Research Paper SO-236:1-23.

Bale, J. S. 2002. Insects and low temperatures: from molecular biology to distributions and abundance. Philosophical Transactions of the Royal Society B: Biological Sciences 357:849-861.

Battisti, A., M. Stastny, S. Netherer, C. Robinet, A. Schopf, A. Roques, and S. Larsson. 2005. Expansion of geographic range in the pine processionary moth caused by increased winter temperatures. Ecological Applications 15:2084-2096.

Beal, J. A. 1933. Temperature extremes as a factor in the ecology of the southern pine beetle. Journal of Forestry 31: 329-336.

Beal, J. A. 1934. Relation of air and bark temperatures of infested ponderosa pines during subzero weather. Journal of Economic Entomology 27:1132-1139.

Bentz, B. J., J. A. Logan, and J. C. Vandygriff. 2001. Latitudinal variation in Dendroctonus ponderosae (Coleoptera: Scolytidae) development time and adult size. Canadian Entomologist 133:375-387.

Bentz, B. J., and D. E. Mullins. 1999. Ecology of mountain pine beetle (Coleoptera: Scolytidae) cold hardening in the Intermountain West. Environmental Entomology 28:577587.

Billings, R. F. 1988. Forecasting southern pine beetle population trends with pheromone traps. Pages $1295-1306$ in T. L.
Payne and H. Saarenmaa, editors. Integrated control of Scolytid bark beetles: Proceedings of the IUFRO Working Party and XVII International Congress of Entomology Symposium "Integrated control of Scolytid bark beetles." Virginia Polytechnic Institute and State University, Blacksburg, Virginia, USA.

Billings, R. F., S. R. Clarke, V. Espino Mendoza, P. Cordón Cabrera, B. Meléndez Figueroa, J. Ramón Campos, and G. Baeza. 2004. Bark beetle outbreaks and fire: a devastating combination for Central America's pine forests. Unasylva 217:15-21.

Billings, R. F., and J. D. Ward. 1984. How to conduct a southern pine beetle aerial detection survey. Circular 267. USDA Forest Service, Washington, D.C., USA. 〈http:// www.fs.fed.us/r8/foresthealth/pubs/circ267/circ267.htm $\rangle$

Bjørnstad, O. N., R. A. Ims, and X. Lambin. 1999. Spatial population dynamics: analyzing patterns and processes of population synchrony. Trends in Ecology and Evolution 14: 427-432.

Bolstad, P. V., B. J. Bentz, and J. A. Logan. 1997. Modelling micro-habitat temperature for Dendroctonus ponderosae (Coleoptera: Scolytidae). Ecological Modelling 94:287-297.

Broggi, J., M. Orell, E. Hohtola, and J. A. Nilson. 2004. Metabolic response to temperature variation in the great tit: an interpopulation comparison. Journal of Animal Ecology 73:967-972.

Brown, J. H., J. F. Gillooly, A. P. Allen, V. M. Savage, and G. B. West. 2004. Toward a metabolic theory of ecology. Ecology 85:1771-1789.

Byers, J. A. 2000. Wind-aided dispersal of simulated bark beetles flying through forests. Ecological Modelling 125:231243.

Cade, B. S., and B. R. Noon. 2003. A gentle introduction to quantile regression for ecologists. Frontiers in Ecology and the Environment 1:412-420.

Carrillo, M. A., C. A. Cannon, W. F. Wilcke, R. V. Morey, N. Kaliyan, and W. D. Hutchison. 2005a. Relationship between supercooling point and mortality at low temperatures in Indianmeal moth (Lepidoptera : Pyralidae). Journal of Economic Entomology 98:618-625.

Carrillo, M. A., R. L. Koch, E. C. Burkness, K. Bennett, D. W. Ragsdale, and W. D. Hutchison. 2005b. Supercooling point of bean leaf beetle (Coleoptera: Chrysomelidae) in Minnesota and a revised predictive model for survival at low temperatures. Environmental Entomology 34:1395-1401.

Carroll, A. L., S. W. Taylor, J. Régnière, and L. Safranyik. 2004. Effects of climate and climate change on the mountain pine beetle. Pages 223-232 in T. L. Shore, J. E. Brooks, and J. E. Stone, editors. Proceedings of the mountain pine beetle symposium: challenges and solutions. Information Report BC-X-399. Canadian Forest Service, Pacific Forestry Centre, Victoria, British Columbia, Canada.

Chen, B., and L. Kang. 2005. Implication of pupal cold tolerance for the northern over-wintering range limit of the leafminer Liriomyza sativae (Diptera: Agromyzidae) in China. Applied Entomology and Zoology 40:437-446.

Clarke, S. R., and R. F. Billings. 2003. Analysis of the southern pine beetle suppression program on the National Forests in Texas in the 1990s. Southern Journal of Applied Forestry 27: $122-129$.

Clarke, S., R. Evans, and R. Billings. 2000. Influence of pine bark beetles on the west Gulf Coastal Plain. Texas Journal of Science 52:105-126.

Cronin, J. T., J. D. Reeve, R. Wilkens, and P. Turchin. 2000. The pattern and range of movement of a checkered beetle predator relative to its bark beetle prey. Oikos 90:127-138.

Crozier, L. 2004. Warmer winters drive butterfly range expansion by increasing survivorship. Ecology 85:231-241. 
Dale, V. H., et al. 2001. Climate change and forest disturbances. BioScience 51:723-734.

Davidson, J., and H. G. Andrewartha. 1948. The influence of rainfall, evaporation and atmospheric temperature on fluctuations in the size of a natural population of Thrips imaginis (Thysanoptera). Journal of Animal Ecology 17:200222.

Dittman, D. E. 1997. Latitudinal compensation in oyster ciliary activity. Functional Ecology 11:573-578.

Edmunds, P. J. 2005. The effect of sub-lethal increases in temperature on the growth and population trajectories of three Scleractinian corals on the southern Great Barrier Reef. Oecologia 146:350-364.

Flamm, R. O., P. E. Pulley, and R. N. Coulson. 1993. Colonization of disturbed trees by the southern pine bark beetle guild (Coleoptera, Scolytidae). Environmental Entomology 22:62-70.

Freon, P., P. Cury, L. Shannon, and C. Roy. 2005. Sustainable exploitation of small pelagic fish stocks challenged by environmental and ecosystem changes: a review. Bulletin of Marine Science 76:385-462.

Georgiadis, N., M. Hack, and K. Turpin. 2003. The influence of rainfall on zebra population dynamics: implications for management. Journal of Applied Ecology 40:125-136.

Gurney, W. S. C., D. C. Speirs, S. N. Wood, E. D. Clarke, and M. R. Heath. 2001. Simulating spatially and physiologically structured populations. Journal of Animal Ecology 70:881894.

Helmuth, B., J. G. Kingsolver, and E. Carrington. 2005. Biophysics, physiological ecology, and climate change: Does mechanism matter? Annual Review of Physiology 67:177201.

Hofstetter, R. W., J. T. Cronin, K. D. Klepzig, J. C. Moser, and M. P. Ayres. 2006. Antagonisms, mutualisms and commensalisms affect outbreak dynamics of the southern pine beetle. Oecologia 147:679-691.

Huey, R. B., and P. E. Hertz. 1984. Is a jack-of-all-temperatures a master of none? Evolution 38:441-444.

Humphries, M. M., J. Umbanhowar, and K. S. McCann. 2004. Bioenergetic prediction of climate change impacts on northern mammals. Integrative and Comparative Biology 44:152-162.

Jacobson, A. R., A. Provenzale, A. Von Hardenberg, B. Bassano, and M. Festa-Bianchet. 2004. Climate forcing and density dependence in a mountain ungulate population. Ecology 85:1598-1610.

Jenouvrier, S., C. Barbraud, and H. Weimerskirch. 2003. Effects of climate variability on the temporal population dynamics of southern fulmars. Journal of Animal Ecology 72:576-587.

Jin, M. L., R. E. Dickinson, and D. L. Zhang. 2005. The footprint of urban areas on global climate as characterized by MODIS. Journal of Climate 18:1551-1565.

Karban, R., and S. Y. Strauss. 2004. Physiological tolerance, climate change, and a northward range shift in the spittlebug, Philaenus spumarius. Ecological Entomology 29:251-254.

Kearney, M., and W. P. Porter. 2004. Mapping the fundamental niche: physiology, climate, and the distribution of a nocturnal lizard. Ecology 85:3119-3131.

Koenker, R., and G. Bassett. 1978. Regression quantiles. Econometrica 46:33-50.

Kokko, H., J. Lindstrom, and E. Ranta. 1997. Risk analysis of hunting of seal populations in the Baltic. Conservation Biology 11:917-927.

Kukal, O., M. P. Ayres, and J. M. Scriber. 1991. Cold tolerance of pupae in relation to the distribution of swallowtail butterflies. Canadian Journal of Zoology 69:3028-3037.

Layne, J. R., C. L. Edgar, and R. E. Medwith. 1999. Cold hardiness of the woolly bear caterpillar (Pyrrharctia isabella
Lepidoptera: Arctiidae). American Midland Naturalist 141: 293-304.

Lele, S., M. L. Taper, and S. Gage. 1998. Statistical analysis of population dynamics in space and time using estimating functions. Ecology 79:1489-1502.

Lloyd, A. H., A. E. Wilson, C. L. Fastie, and R. M. Landis. 2005. Population dynamics of black spruce and white spruce near the arctic tree line in the southern Brooks Range, Alaska. Canadian Journal of Forest Research 35:2073-2081.

Logan, J. A., and B. J. Bentz. 1999. Model analysis of mountain pine beetle (Coleoptera: Scolytidae) seasonality. Environmental Entomology 28:924-934.

Logan, J. A., J. Régnière, and J. A. Powell. 2003. Assessing the impacts of global warming on forest pest dynamics. Frontiers in Ecology and the Environment 1:130-137.

Lombardero, M. J., M. P. Ayres, B. D. Ayres, and J. D. Reeve. 2000. Cold tolerance of four species of bark beetle (Coleoptera: Scolytidae) in North America. Environmental Entomology 29:421-432.

Lorio, P. L., Jr. 1993. Environmental stress and whole-tree physiology. Pages 81-101 in T. D. Schowalter and G. M. Filip, editors. Beetle-pathogen interactions in conifer forests. Academic Press, London, UK.

Lourdais, O., R. Shine, X. Bonnet, M. Guillon, and G. Naulleau. 2004. Climate affects embryonic development in a viviparous snake, Vipera aspis. Oikos 104:551-560.

McClelland, W. T., and F. P. Hain. 1979. Survival of declining Dendroctonus frontalis populations during a severe and nonsevere winter. Environmental Entomology 8:231-235.

Miller, L. K., and R. A. Werner. 1987. Cold-hardiness of adult and larval spruce beetles Dendroctonus rufipennis (Kirby) in interior Alaska. Canadian Journal of Zoology 65:2927-2930.

Moberg, A., D. M. Sonechkin, K. Holmgren, N. M. Datsenko, and W. Karlen. 2005. Highly variable Northern Hemisphere temperatures reconstructed from low- and high-resolution proxy data. Nature 433:613-617.

Nedved, O., D. Lavy, and H. A. Verhoef. 1998. Modelling the time-temperature relationship in cold injury and effect of high-temperature interruptions on survival in a chill-sensitive collembolan. Functional Ecology 12:816-824.

Oerlemans, J. 2005. Extracting a climate signal from 169 glacier records. Science 308:675-677.

Parmesan, C., and G. Yohe. 2003. A globally coherent fingerprint of climate change impacts across natural systems. Nature 421:37-42.

Pascual, M., X. Rodo, S. P. Ellner, R. Colwell, and M. J. Bouma. 2000. Cholera dynamics and El Nino-Southern Oscillation. Science 289:1766-1769.

Payne, T. L. 1980. Life history and habits. Pages 7-28 in R. C. Thatcher, J. L. Searcy, J. E. Coster, and G. D. Hertel, editors. The southern pine beetle. Technical Bulletin 1631, USDA Forest Service, Combined Forest Pest Research and Development Program, Pineville, Louisiana, USA.

Pearson, R. G., and T. P. Dawson. 2003. Predicting the impacts of climate change on the distribution of species: Are bioclimate envelope models useful? Global Ecology and Biogeography 12:361-371.

Powell, J. A., J. L. Jenkins, J. A. Logan, and B. J. Bentz. 2000. Seasonal temperature alone can synchronize life cycles. Bulletin of Mathematical Biology 62:977-998.

Price, T. S., H. C. Dogget, J. M. Pye, and B. Smith. 1997. A history of southern pine beetle outbreaks in the southeastern United States. Georgia Forestry Commission, Macon, Georgia, USA.

Ragenovich, I. 1980. Effects of subzero Fahrenheit temperatures on southern pine beetle Dendroctonus frontalis populations in the southern Appalachians, USA. Southern Journal of Applied Forestry 4:201-203. 
Reeve, J. D., D. J. Rhodes, and P. Turchin. 1998. Scramble competition in the southern pine beetle, Dendroctonus frontalis. Ecological Entomology 23:433-443.

Régnière, J., and A. Sharov. 1999. Simulating temperaturedependent ecological processes at the sub-continental scale: male gypsy moth flight phenology as an example. International Journal of Biometeorology 42:146-152.

Renault, D., C. Salin, G. Vannier, and P. Vernon. 2002. Survival at low temperatures in insects: what is the ecological significance of the supercooling point? Cryoletters 23:217228.

Reynolds, L. V., M. P. Ayres, T. G. Siccama, and R. T. Holmes. In press. Climatic effects on caterpillar fluctuations in northern hardwood forests. Canadian Journal of Forest Research.

Root, T. L., J. T. Price, K. R. Hall, S. H. Schneider, C. Rosenzweig, and J. A. Pounds. 2003. Fingerprints of global warming on wild animals and plants. Nature 421:57-60.

Sæther, B. E., J. Tufto, S. Engen, K. Jerstad, O. W. Rostad, and J. E. Skatan. 2000. Population dynamical consequences of climate change for a small temperate songbird. Science 287: 854-856.

Safranyik, L., and A. L. Carroll. 2005. The biology and epidemiology of the mountain pine beetle in lodgepole pine forests. Pages 3-66 in L. Safranyik and B. Wilson, editors. The mountain pine beetle: a synthesis of its biology and management in lodgepole pine. Natural Resources Canada, Canadian Forest Service, Ottawa, Ontario, Canada.

Sharov, A. A., and A. M. Liebhold. 1998. Model of slowing the spread of gypsy moth (Lepidoptera: Lymantriidae) with a barrier zone. Ecological Applications 8:1170-1179.

Sharov, A. A., B. C. Pijanowski, A. M. Liebhold, and S. H. Gage. 1999. What affects the rate of gypsy moth (Lepidoptera: Lymantriidae) spread: winter temperature or forest susceptibility? Agricultural and Forest Entomology 1:37-45.

Shirley, M. D. F., S. P. Rushton, A. G. Young, and G. R. Port. 2001. Simulating the long-term dynamics of slug populations: a process-based modelling approach for pest control. Journal of Applied Ecology 38:401-411.

Somme, L. 1982. Supercooling and winter survival in terrestrial arthropods. Comparative Biochemistry and Physiology A 73A:519-543.

Stenseth, N. C., A. Mysterud, G. Ottersen, J. W. Hurrell, K. S. Chan, and M. Lima. 2002. Ecological effects of climate fluctuations. Science 297:1292-1296.

Stevenson, I. R., and D. M. Bryant. 2000. Avian phenologyclimate change and constraints on breeding. Nature 406:366367.
Thatcher, R. C. 1967. Winter brood development of southern pine beetle in southeast Texas. Journal of Economic Entomology 60:599-600.

Thatcher, R. C., and P. J. Barry. 1982. Southern pine beetle. Forest Insect and Disease Leaflet 49. USDA Forest Service, Washington, D.C., USA.

Thatcher, R. C., J. L. Searcy, J. E. Coster, and G. D. Hertel. 1980. The southern pine beetle. Technical Bulletin 1631, USDA Forest Service, Combined Forest Pest Research and Development Program, Pineville, Louisiana, USA.

Turchin, P., P. L. Lorio, Jr., A. D. Taylor, and R. F. Billings. 1991. Why do populations of southern pine beetles (Coleoptera: Scolytidae) fluctuate? Environmental Entomology 20: 401-409.

Turchin, P., and A. D. Taylor. 1992. Complex dynamics in ecological times series. Ecology 73:289-305.

Turchin, P., A. D. Taylor, and J. D. Reeve. 1999. Dynamical role of predators in population cycles of a forest insect: an experimental test. Science 285:1068-1071.

Turchin, P., and W. T. Thoeny. 1993. Quantifying dispersal of southern pine beetles with mark-recapture experiments and a diffusion model. Ecological Applications 3:187-198.

Ungerer, M. J., M. P. Ayres, and M. J. Lombardero. 1999. Climate and the northern distribution limits of Dendroctonus frontalis Zimmermann (Coleoptera: Scolytidae). Journal of Biogeography 26:1133-1145.

Volney, W. J. A., and K. G. Hirsch. 2005. Disturbing forest disturbances. Forestry Chronicle 81:662-668.

Vucetich, J. A., D. W. Smith, and D. R. Stahler. 2005. Influence of harvest, climate and wolf predation on Yellowstone elk, 1961-2004. Oikos 111:259-270.

Walther, G. R., E. Post, P. Convey, A. Menzel, C. Parmesan, T. J. C. Beebee, J. M. Fromentin, O. Hoegh-Guldberg, and F. Bairlein. 2002. Ecological responses to recent climate change. Nature 416:389-395.

Wilent, S. 2005. Mountain pine beetles threaten Canadian, U.S. forests. The Forestry Source, May. 〈http://www.safnet.org/ archive $/ 0505$ _beetle.cfm $\rangle$

Ylioja, T., D. H. Slone, and M. P. Ayres. 2005. Mismatch between herbivore behavior and demographics explains scale-dependence of host susceptibility in two pine species. Forest Science 51:522-531.

Yonow, T., M. P. Zalucki, R. W. Sutherst, B. C. Dominiak, G. F. Maywald, D. A. Maelzer, and D. J. Kriticos. 2004. Modelling the population dynamics of the Queensland fruit fly, Bactrocera (Dacus) tryoni: a cohort-based approach incorporating the effects of weather. Ecological Modelling 173:9-30. 